\title{
Assessment of Trace and Rare Earth Element Levels in Stream Sediments in ljero-Ekiti Area, Southwest Nigeria
}

\author{
H. Y. Madukwe* ${ }^{* \dagger, ~ O . ~ A . ~ I b i g b a m i * * ~ a n d ~ R . ~ A . ~ O b a s i * ~}$ \\ *Department of Geology, Ekiti State University, PMB 5363, Ado-Ekiti, Nigeria \\ **Department of Chemistry, Ekiti State University, PMB 5363, Ado-Ekiti, Nigeria \\ $†$ Corresponding author: H. Y. Madukwe; henry.madukwe@eksu.edu.ng
}

Nat. Env. \& Poll. Tech

Website: www.neptjournal.com

Received: 03-06-2019

Accepted: 24-07-2019

\section{Key Words:}

Sediments; Trace elements;

Rare earth elements;

Enrichment factor; Pollution load index

\begin{abstract}
The study considered the level, sources and extent of trace and rare earth elements (REE) contamination in Agbangudu stream sediments in Ekiti State, Southwestern Nigeria. The samples were analysed with Laser Ablation Inductively Coupled Plasma Spectrometer (LA-ICP-MS). The trace and rare earth elements' concentration ranged from 0.50 (Mo) to 750 (Ba) and 0.16 (Lu) to 175 (Ce) ppm respectively. The results revealed that the sediments are not that enriched in REEs. The Pollution Load Index (PLI) indicates baseline levels of the metals. The geochemical index (Igeo) of the elements revealed uncontaminated to moderately contaminated, except for Cs and Ta with strongly to extremely contaminated status. The Average Shale Value (AVS) and the Upper Continental Crust (UCC) normalized REE distribution patterns of the sediments. To establish the relationship between the metals, Principal Component Analysis (PCA) and Clusters Analysis (CA) were used as classification techniques. Despite the common occurrences of the elements, their overall patterns were much different as revealed by the cluster analysis.
\end{abstract}

\section{INTRODUCTION}

Sediments are transported and deposited particles or aggregates derived from rocks, soils or biological material (SSSA 2008). Generally, stream sediments are composed of weathering products of basement rocks introduced into streams. Studies of the chemistry of stream sediments have been used in mineral prospecting (Levinson 1974, Rose et al. 1979, Hale \& Plant 1994) and environmental studies (Förstner 1983, Howarth \& Thornton 1983, Förstner et al. 1991). Most streams in southwestern Nigeria are located on the Basement complex, which lies within the reactivated part of the Pan-African mobile belt between the West African and Congo Cratons (Kennedy 1965). The geochemical compositions of stream sediments reflect the average composition of an entire drainage basin (Halamic et al. 2001, Reimann \& Melezhik 2001). According to Grunsky \& Sutphin (2009), geochemical studies based on the chemical analysis of active stream sediments are an effective tool with several applications. The expression "rare earth elements" (REEs) does not infer that they are rare in nature; rather, REEs are relatively abundant in the earth. The total contents of REEs exceed $200 \mathrm{ppm}$ in the average crust. Some REEs are even more common than copper or lead in the crust (Castor \& James 2006, Chen 2011). REEs are at the lower part of the Periodic Table, which includes 15 lanthanides (from lanthanum to lutetium) and two other elements: scandium and yttrium. These 17 elements form a coherent group with similar chemical properties. Usually, REEs can be divided into three groups by their atomic number and masses - the light rare earth elements (LREE), which comprises of La, $\mathrm{Ce}$, and Pr, the middle rare earth elements (MREE), made up of $\mathrm{Nd}, \mathrm{Sm}, \mathrm{Eu}$, and $\mathrm{Gd}$, while the heavy rare earth elements (HREE) include those from Tb to Lu (EPA 2012).

Trace and rare earth elements in sediments are derived from both natural (geogenic) and anthropogenic sources. Heavy metals and rare earth elements (REEs) are potentially toxic substances in ecosystems. According to Lin et al. (2008), heavy metals and REEs are added to the hydrological system by natural processes such as rock weathering, volcanic eruption and long-distance atmospheric deposits. In recent times, the chief sources of these elements are due to the human activities: industrialization, agriculture, urban development and waste discharge (Senesi et al. 1999, Ochieng et al. 2007, Chen et al. 2013, Ong et al. 2013, Sofianska \& Michailidis 2013, Zhuang et al. 2013). Stream sediments contamination by heavy metals has become a widespread serious problem in many parts of the world (Sofianska \& Michailidis 2013). Trace and rare earth element contamination in soils has attracted so much attention because of the hazard it poses to human health (Loska et al. 2004). Rivers, 
streams and sediments are contaminated by trace elements such as: $\mathrm{As}, \mathrm{Fe}, \mathrm{Hg}, \mathrm{Mn}$ and $\mathrm{Pb}$ from artisanal mining activities, and their values have also been found to exceed standard safety levels (Ojo \& Oketayo 2006, Nartey et al. 2011). Some metals like $\mathrm{Fe}, \mathrm{Cu}, \mathrm{Co}, \mathrm{Mn}, \mathrm{Cr}$ and $\mathrm{Zn}$ are essential micronutrients, but they can be detrimental to man and other living organisms at higher concentrations (Nurnberg 1982, Kar et al. 2008, Nair et al. 2010). According to Wakida et al. (2008), industrial waste reaching the sea via atmospheric precipitation and dumping of urban and rural waste is mostly responsible for the input of trace elements into the marine and stream environments, which are afterwards incorporated into the sediments. Trace and rare earth elements are serious pollutants because of their toxicity, persistent and non-degradability and thus imparting into the water and debasing its quality in an environment (Tijani et al. 2005). Several studies have shown the harmful effects and health hazards of REEs to human beings, and it has already been proven that longterm exposure of REE dust may cause pneumoconiosis in humans (Hirano \& Suzuki 1996).
This work analyses trace and rare earth elements concentration in the Agbangudu stream sediments and pollution indices such as enrichment factor (EF), contamination factor (CF), pollution load index (PLI), degree of contamination (DC) and geochemical index (Igeo).

\section{MATERIALS AND METHODS}

\section{Study Area}

Ijero-Ekiti is located $42 \mathrm{~km}$ northwest of Ado-Ekiti, the state capital, and lies between longitudes $5^{\circ} 00^{\prime} \mathrm{E}$ and $5^{\circ} 07^{\prime} \mathrm{E}$, and latitudes $7^{\circ} 46^{\prime} \mathrm{N}$ and $7^{\circ} 53^{\prime} \mathrm{N}$. The Ijero-Ekiti area is underlain by the basement complex rocks of Southwest, Nigeria (Fig. 1). The local geology consists of the migmatite gneiss, quartzite, schist biotite gneiss, calc-gneiss, epidiorite, biotite schist, amphibole schist, granite and pegmatite (Fig. 2). Fig. 3 shows the Ijero area and the sampling points.

The migmatite gneiss occurs within the eastern part covering about two-fifth of the area, biotite gneiss predominantly

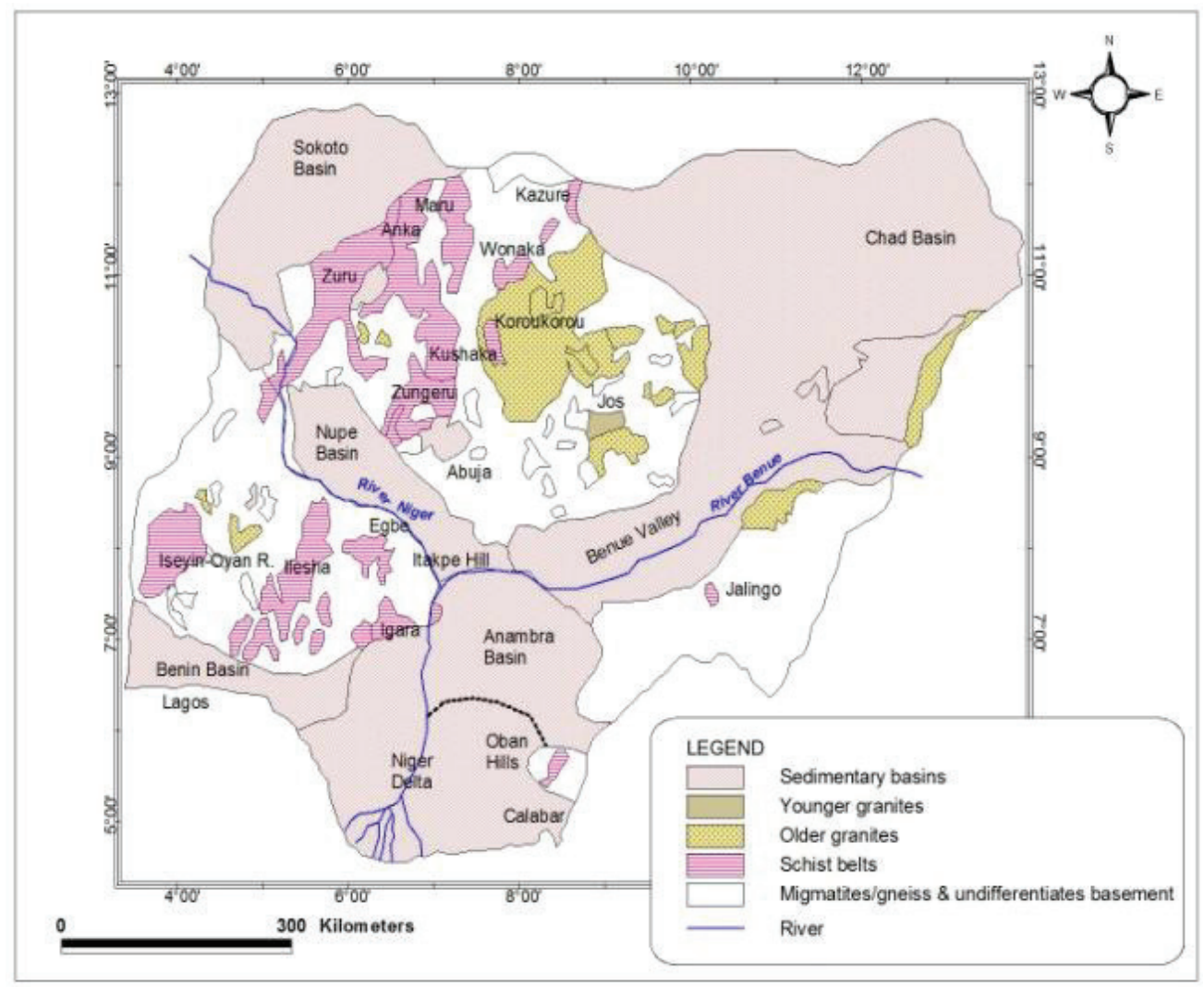

Fig. 1: Geological map of Nigeria showing basement complex, schist belts, and sedimentary terrain (After Akinola et al. 2014). 


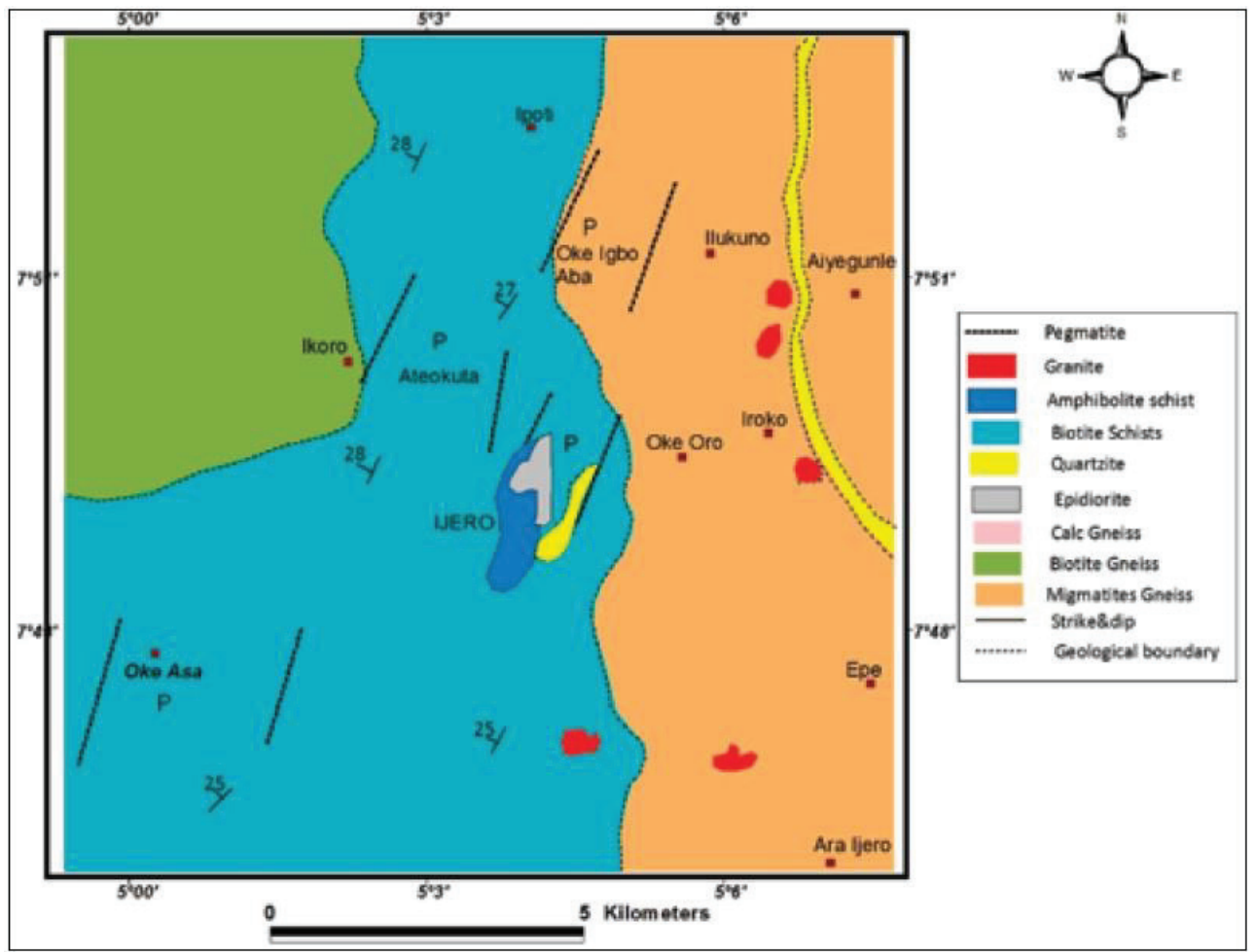

Fig. 2: Geological map of Ijero Ekiti area (After Okunlola \& Akinola 2010).

covers the northwest (the gneissic rocks are essentially highly foliated and denuded); calc-gneiss and quartzite occupy a narrow NE-SW strip around Ijero-Ekiti town (Okunlola \& Akinola 2010). Epidiorite occurs as the major ultramafic assemblage while amphibole schist and biotite schist occupy the central, low-lying area that is occasionally pulsed with granites and pegmatite intrusions now exposed due to prolonged weathering activities. The pegmatite occurs as very coarse-grained dykes, dykelets and sometimes of extensive dimension (Okunlola \& Akinola 2010). Steeply dipping complex pegmatite around Ijero-Ekiti typically consists of an outer medium-grained microcline-albite-quartz-muscovite zone, an intermediate zone comprising coarse-grained microcline-albite-quartz, blocky microcline-quartz, coarse-grained quartz or lepidolite-quartz and finally, a core of coarsegrained muscovite-quartz and quartz (Okunlola 2005). Several workers have worked on the geology, tectonics, etc., of the Nigerian Precambrian Basement complex (Burke \& Dewey 1972, Oyawoye 1972, Rahaman 1976, Rahaman \& Ocan 1978, Black et al. 1979, Turner 1983, Ajibade et al. 1987, Rahaman 1988).

\section{Sample Pre-treatment}

Several samples were initially obtained while 10 , which were representative of the stream channels, were eventually selected and analysed. Samples were taken at a depth of $20-25 \mathrm{~cm}$ and bagged and labelled to avoid mix up. The geographical locations of each sample collected were noted and recorded in the field notebook. The samples were air-dried, pulverized, homogenized, packaged and sent to the laboratory in Stellenbosch University, South Africa for geochemical analysis. The trace and rare elemental data for this work were acquired using Laser Ablation inductively coupled plasma spectrometer (LA-ICP-MS) analyses. LA-ICP-MS is a powerful and sensitive analytical technique for multi-elemental analysis. The laser was used to vaporize the surface of the solid sample, while the vapour, and any particles, were then transported by the carrier gas flow to the ICP-MS.

The analytical results were compiled to form a multi-elemental database using Excel and Past. The statistical analyses, including principal component analysis (PCA) and cluster analysis (CA), were performed using Past statistical software.

\section{RESULTS AND DISCUSSION}

\section{Distribution of Trace and Rare Earth Elements}

The trace and rare elements composition, average values, background values of the Ijero stream sediments sampled, 


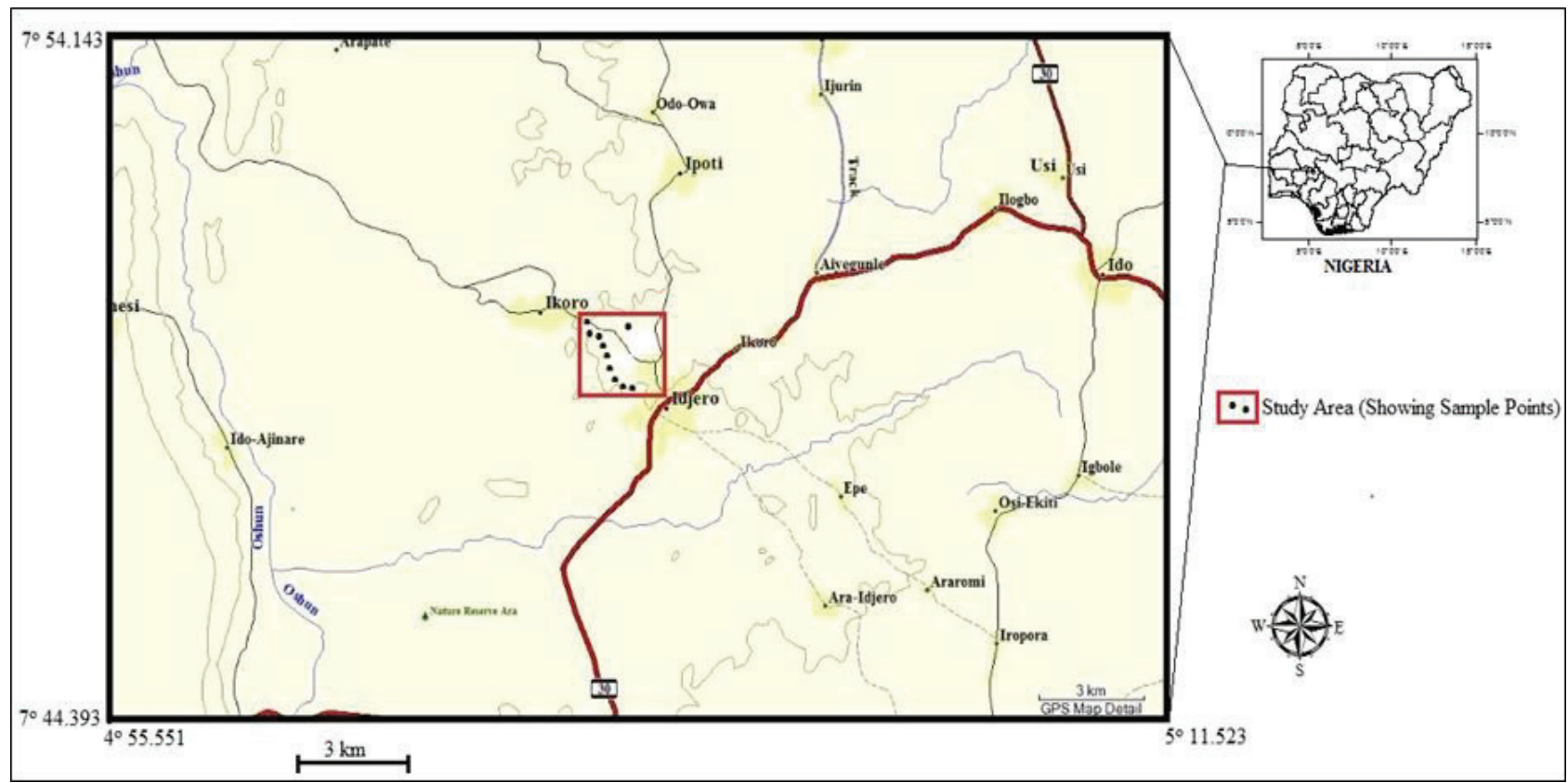

Fig. 3: The study area showing the sampling points.

upper continental crust values and average shale values are presented in Table 1. The background or control sample is the normal abundance of uncontaminated background levels in the stream sediments. These data revealed that the mean values of $\mathrm{V}, \mathrm{Co}, \mathrm{Cu}, \mathrm{Zr}, \mathrm{Nb}, \mathrm{Hf}$, Th, Mo and REEs: $\mathrm{La}, \mathrm{Ce}$, $\mathrm{Pr}, \mathrm{Nd}, \mathrm{Sm}, \mathrm{Sc}$, are below the background values, while $\mathrm{Cr}$, $\mathrm{Ni}, \mathrm{Zn}, \mathrm{Rb}, \mathrm{Sr}, \mathrm{Cs}$, Ba and the REEs: Eu, Gd, Tb, Dy, Er, Tm, $\mathrm{Yb}, \mathrm{Lu}, \mathrm{Y}$, exceeded the background values. These elements with higher concentrations than the background values could become a major cause of concern. Figs. 4 and 5 are bivariate plots comparing trace element concentration and REE concentration of the samples studied with the mean of the upper continental crust and the average shale value respectively. $\mathrm{Zn}, \mathrm{Rb}, \mathrm{Zr}$, and $\mathrm{Nb}$ showed significant enrichment compared to UCC and AVS. For the REEs, the concentrations showed the same pattern with the UCC and AVS. Fig. 6 is an AVS and UCC-normalized trace elements patterns for the stream sediments showing high levels of $\mathrm{Nb}$ and $\mathrm{Ta}$, and to a lesser extent $\mathrm{Rb}, \mathrm{Zn}, \mathrm{Cs}$ and Hf. The AVS and UCC-normalized REE patterns for the stream sediments show an almost flat pattern, which might suggest the stream sediments are not that enriched in REEs (Fig. 7).

\section{Enrichment Factor}

Enrichment Factor (EF) is a useful pointer in assessing the level of contamination in an environment. According to Hernandez et al. (2003), the enrichment factor is the relative abundance of a chemical element in stream sediment compared to the bedrock. EF evaluates the degree of anthropogenic influence on element load in sediments and differentiates between elements of geogenic or anthropogenic origin (Fagbote \& Olanipekun 2010). Enrichment factor values of trace and rare earth elements in the Agbangudu stream sediments are presented in Table 2. It was calculated using the formula originally introduced by Buat-Menard \& Chesselet (1979):

$$
\mathrm{EF}=\left(\mathrm{C}_{\mathrm{n}} / \mathrm{C}_{\text {ref }}\right)_{\text {sample }} /\left(\mathrm{B}_{\mathrm{n}} / \mathrm{B}_{\text {ref }}\right)_{\text {background }}
$$

Where, $C_{n}$ is the concentration of the examined element in the examined environment; $\mathrm{C}_{\text {ref }}$ is the concentration of the reference element in the examined environment; $B_{n}$ is the background value of the examined element, and $\mathrm{B}_{\text {ref }}$ is the background value of the reference element. The method by Salomons \& Forstner (1984) was used, which entails comparing the present-day metal concentrations in sediments with standard earth materials as a normalizer in average shale.

Average shale value (AVS) and control value from Turekian \& Wedepohl (1961), UCC: Upper Continental Crust (Taylor \& McLennan 1985, 1995)

The global average shale is frequently employed to provide background metal levels; the element's concentration 
Table 1: Chemical composition (ppm) of trace and rare earth elements in the stream sediment

\begin{tabular}{|c|c|c|c|c|c|c|c|c|c|c|c|c|c|c|}
\hline \multirow{2}{*}{ Elements } & \multicolumn{10}{|c|}{ SAMPLE ID } & \multirow{2}{*}{ Mean } & \multirow{2}{*}{$\begin{array}{l}\text { Control } \\
\text { sample }\end{array}$} & \multirow{2}{*}{ ASV } & \multirow{2}{*}{$\mathrm{UCC}$} \\
\hline & AG-1 & AG-2 & AG-3 & AG-4 & AG-5 & AG-6 & AG-7 & AG-8 & AG-9 & AG-10 & & & & \\
\hline V & 85.54 & 112.76 & 68.83 & 69.07 & 46.87 & 56.93 & 62.47 & 61.52 & 115.41 & 53.16 & 73.26 & 86.43 & 130 & 107 \\
\hline $\mathrm{Cr}$ & 151.38 & 211.07 & 86.39 & 84.29 & 54.21 & 67.57 & 244.49 & 58.37 & 79.47 & 45.84 & 108.31 & 30.04 & 90 & 85 \\
\hline Co & 16.56 & 24.74 & 10.38 & 12.34 & 6.91 & 9.26 & 24.05 & 9.43 & 9.05 & 5.02 & 12.77 & 431.16 & 19 & 17 \\
\hline $\mathrm{Ni}$ & 60.39 & 85.44 & 33.96 & 31.94 & 18.74 & 24.6 & 56.34 & 18.77 & 29.31 & 13.72 & 37.27 & 10.24 & 50 & 20 \\
\hline $\mathrm{Cu}$ & 22.06 & 24.86 & 16.28 & 13.73 & 8.04 & 18.43 & 15.9 & 19.93 & 32.5 & 15.54 & 18.73 & 19.54 & 45 & 25 \\
\hline $\mathrm{Zn}$ & 146.9 & 107.94 & 128.61 & 94.81 & 76.3 & 116.2 & 113.76 & 206.61 & 171.71 & 242.64 & 140.53 & 67.37 & 95 & 71 \\
\hline $\mathrm{Rb}$ & 317.34 & 292.35 & 363.46 & 363.75 & 449.51 & 406.48 & 323.89 & 253.69 & 330.87 & 220.87 & 332.22 & 59.17 & 140 & 112 \\
\hline $\mathrm{Sr}$ & 145.58 & 117.11 & 67.16 & 101.1 & 74.88 & 72.55 & 181.55 & 119.72 & 36.06 & 27.41 & 94.31 & 75.87 & 170 & 350 \\
\hline $\mathrm{Zr}$ & 468.62 & 524.06 & 341.4 & 386.98 & 436 & 440.37 & 170.08 & 565.6 & 407.85 & 580.99 & 432.2 & 5573 & 160 & 190 \\
\hline $\mathrm{Nb}$ & 204.05 & 112.54 & 114.32 & 226.24 & 132.57 & 188.13 & 108.09 & 292.49 & 127.68 & 214.27 & 172.04 & 280.5 & 11 & 12 \\
\hline Mo & 0.77 & 0.63 & 0.66 & 0.59 & 0.5 & 0.77 & 0.75 & 0.77 & 1.56 & 0.52 & 0.69 & 1.4 & 2.6 & 1.5 \\
\hline Cs & 12.85 & 14.83 & 17.18 & 11.42 & 10.25 & 11.7 & 16.05 & 7.89 & 18.03 & 9.15 & 12.94 & 0.28 & 5 & 4.6 \\
\hline $\mathrm{Ba}$ & 317.77 & 343.6 & 311.66 & 361.12 & 281.17 & 272.79 & 750.85 & 368.04 & 274.87 & 210.53 & 349.24 & 123.43 & 580 & 550 \\
\hline $\mathrm{Hf}$ & 14.84 & 14.82 & 10.3 & 10.81 & 12.83 & 12.86 & 5.04 & 20.64 & 11.87 & 15.89 & 12.99 & 26.23 & 5 & 5.8 \\
\hline $\mathrm{Ta}$ & 125.97 & 32.55 & 32.2 & 77.29 & 45.57 & 48.67 & 16.49 & 49.55 & 32.97 & 43.95 & 50.521 & 1.02 & 1 & 1 \\
\hline $\mathrm{Pb}$ & 20.22 & 21.13 & 26.16 & 26.99 & 21.7 & 25.54 & 31.53 & 31.19 & 22.53 & 16.61 & 24.36 & 15.21 & 20 & 17 \\
\hline Th & 13.69 & 13.01 & 7.18 & 7.86 & 11.01 & 11.2 & 6.68 & 48.18 & 12.82 & 16.35 & 14.798 & 41.69 & 12 & 10.7 \\
\hline $\mathrm{U}$ & 8.03 & 6.76 & 7.39 & 6.64 & 6.24 & 11.85 & 8.52 & 18.89 & 9.52 & 4.7 & 8.854 & 4.25 & 2.7 & 2.8 \\
\hline $\mathrm{La}$ & 47.12 & 53.96 & 27.82 & 33.92 & 40.42 & 32.97 & 23.94 & 82.28 & 35.18 & 47.05 & 42.466 & 74.11 & 43 & 30 \\
\hline $\mathrm{Ce}$ & 102.19 & 113.75 & 58.73 & 72.96 & 80.86 & 72.52 & 51.68 & 175.42 & 63.82 & 97.55 & 88.948 & 163.1 & 82 & 64 \\
\hline $\operatorname{Pr}$ & 11.36 & 12.55 & 6.49 & 7.41 & 9.25 & 7.71 & 5.17 & 19.69 & 7.45 & 11.35 & 9.843 & 15.53 & 9.8 & 7.1 \\
\hline $\mathrm{Nd}$ & 42.33 & 46.32 & 23.91 & 26.95 & 34.41 & 28.34 & 19.69 & 72.53 & 28.44 & 42.97 & 36.589 & 52.21 & 33 & 26 \\
\hline $\mathrm{Sm}$ & 9.57 & 9.47 & 4.95 & 5.02 & 7.1 & 6.37 & 3.62 & 16.1 & 5.85 & 8.04 & 7.609 & 8.07 & 6.2 & 4.5 \\
\hline $\mathrm{Eu}$ & 1.28 & 1.68 & 0.83 & 1.03 & 1.07 & 0.94 & 0.85 & 1.04 & 0.92 & 1.04 & 1.068 & 0.68 & 1.2 & 0.88 \\
\hline $\mathrm{Gd}$ & 7.31 & 7.86 & 4.4 & 3.91 & 5.94 & 5.63 & 3.25 & 12.07 & 5.17 & 6.47 & 6.201 & 5.7 & 5.1 & 3.8 \\
\hline $\mathrm{Tb}$ & 1.05 & 1.1 & 0.76 & 0.62 & 1.05 & 0.95 & 0.42 & 1.93 & 0.97 & 0.93 & 0.978 & 0.64 & 0.84 & 0.64 \\
\hline Dy & 5.09 & 6.1 & 4.37 & 3.78 & 6.6 & 5.06 & 2.55 & 7.72 & 5.91 & 5.66 & 5.284 & 3.27 & 4.7 & 3.5 \\
\hline Но & 0.84 & 1.08 & 0.89 & 0.77 & 1.15 & 0.83 & 0.46 & 0.98 & 1.05 & 1.1 & 0.915 & ND & 1.11 & 0.8 \\
\hline $\mathrm{Er}$ & 2.27 & 3.39 & 2.56 & 2.01 & 3.03 & 2.55 & 1.2 & 1.99 & 3 & 3.02 & 2.502 & 1.88 & 2.5 & 2.3 \\
\hline $\mathrm{Tm}$ & 0.32 & 0.41 & 0.35 & 0.31 & 0.39 & 0.36 & 0.17 & 0.29 & 0.42 & 0.41 & 0.343 & 0.28 & 0.44 & 0.33 \\
\hline $\mathrm{Yb}$ & 2.03 & 2.89 & 2.53 & 2.2 & 2.74 & 2.62 & 1.11 & 2.04 & 3.14 & 3.03 & 2.433 & 2.05 & 2.8 & 2.2 \\
\hline $\mathrm{Lu}$ & 0.32 & 0.45 & 0.36 & 0.3 & 0.47 & 0.38 & 0.16 & 0.31 & 0.42 & 0.43 & 0.36 & 0.31 & 0.42 & 0.32 \\
\hline $\mathrm{Sc}$ & 12.42 & 16.23 & 10.72 & 9.42 & 8.15 & 9.31 & 8.69 & 8.39 & 14.27 & 8.07 & 10.57 & 13.64 & 13 & 13.6 \\
\hline Y & 24.09 & 30.19 & 24.27 & 20.84 & 32.34 & 26.09 & 11.87 & 29.17 & 30.42 & 28.94 & 25.82 & 24.17 & 26 & 22 \\
\hline
\end{tabular}

in average shale obtained from Turekian \& Wedepohl (1961) was used. An element can be considered as a reference element if it is of low occurrence variability and present in the environment in trace amounts (Loska et al. 2003). According to Loska et al. (1997), it is also possible to apply an element of geochemical nature, which occurs in significant amounts in the environment but has no interaction or resistance towards an examined element. A reference element is often a conservative one, unchanged by anthropogenic influences; and the most used reference elements include $\mathrm{Sc}, \mathrm{Mn}, \mathrm{Ti}, \mathrm{Al}, \mathrm{Fe}, \mathrm{Zn}$, etc. (Loska et al. 1997, Mediolla et al. 2008). 
Table 2: Enrichment Factor (EF) of trace and rare earth elements in the stream sediments.

\begin{tabular}{|c|c|c|c|c|c|c|c|c|c|c|c|}
\hline Elements & AGU- 1 & AGU-2 & AGU-3 & AGU-4 & AGU-5 & AGU-6 & AGU-7 & AGU-8 & AGU-9 & AGU-10 & MEAN \\
\hline V & 0.43 & 0.76 & 0.39 & 0.53 & 0.45 & 0.36 & 0.4 & 0.22 & 0.49 & 0.16 & 0.42 \\
\hline $\mathrm{Cr}$ & 1.09 & 2.07 & 0.71 & 0.94 & 0.75 & 0.61 & 2.27 & 0.3 & 0.49 & 0.2 & 0.94 \\
\hline $\mathrm{Co}$ & 0.57 & 1.15 & 0.4 & 0.65 & 0.45 & 0.4 & 0.06 & 0.23 & 0.26 & 0.1 & 0.43 \\
\hline $\mathrm{Ni}$ & 0.78 & 1.5 & 0.5 & 0.64 & 0.47 & 0.4 & 0.94 & 0.17 & 0.33 & 0.11 & 0.58 \\
\hline $\mathrm{Cu}$ & 0.32 & 0.49 & 0.27 & 0.31 & 0.22 & 0.34 & 1.05 & 0.2 & 0.4 & 0.14 & 0.37 \\
\hline $\mathrm{Rb}$ & 1.47 & 1.84 & 1.92 & 2.6 & 4.01 & 2.37 & 1.93 & 0.83 & 1.31 & 0.62 & 1.89 \\
\hline $\mathrm{Sr}$ & 0.56 & 0.61 & 0.29 & 0.6 & 0.55 & 0.35 & 0.89 & 0.32 & 0.12 & 0.06 & 0.44 \\
\hline $\mathrm{Zr}$ & 1.9 & 2.88 & 1.58 & 2.41 & 3.39 & 2.25 & 0.89 & 1.63 & 1.41 & 1.42 & 1.98 \\
\hline $\mathrm{Nb}$ & 11.9 & 8.99 & 7.66 & 20.5 & 14.98 & 13.9 & 8.19 & 12.19 & 6.41 & 7.61 & 11.3 \\
\hline Mo & 0.19 & 0.21 & 0.19 & 0.23 & 0.24 & 0.24 & 0.24 & 0.14 & 0.33 & 0.07 & 0.10 \\
\hline Cs & 1.67 & 2.61 & 2.55 & 2.29 & 2.55 & 1.91 & 2.68 & 0.73 & 2.00 & 0.72 & 1.97 \\
\hline $\mathrm{Ba}$ & 0.36 & 0.52 & 0.4 & 0.62 & 0.6 & 0.39 & 1.08 & 0.29 & 0.26 & 0.14 & 0.47 \\
\hline $\mathrm{Hf}$ & 1.92 & 2.61 & 1.52 & 2.17 & 3.19 & 2.10 & 0.84 & 1.90 & 1.31 & 1.24 & 1.88 \\
\hline $\mathrm{Ta}$ & 81.6 & 28.6 & 23.8 & 77.4 & 56.7 & 39.8 & 13.7 & 22.8 & 18.2 & 17.2 & 38.0 \\
\hline $\mathrm{Pb}$ & 0.65 & 0.93 & 0.97 & 1.35 & 1.35 & 1.04 & 1.32 & 0.72 & 0.62 & 0.33 & 0.93 \\
\hline Th & 0.74 & 0.95 & 0.44 & 0.66 & 1.14 & 0.76 & 0.46 & 1.85 & 0.59 & 0.53 & 0.81 \\
\hline $\mathrm{U}$ & 1.93 & 2.20 & 2.02 & 2.46 & 2.88 & 3.59 & 2.64 & 3.22 & 1.95 & 0.68 & 2.36 \\
\hline $\mathrm{La}$ & 1.45 & 1.29 & 0.81 & 1.14 & 0.91 & 1.03 & 1.34 & 2.17 & 0.86 & 1.10 & 1.21 \\
\hline $\mathrm{Ce}$ & 1.65 & 1.43 & 1.43 & 0.89 & 1.28 & 0.95 & 1.18 & 1.52 & 2.42 & 0.82 & 1.36 \\
\hline Pr & 1.53 & 1.32 & 0.83 & 1.09 & 0.91 & 1.05 & 1.27 & 2.28 & 0.80 & 1.17 & 1.22 \\
\hline $\mathrm{Nd}$ & 1.70 & 1.44 & 0.90 & 1.18 & 1.01 & 1.15 & 1.44 & 2.49 & 0.91 & 1.31 & 1.35 \\
\hline $\mathrm{Sm}$ & 2.04 & 1.57 & 1.00 & 1.17 & 1.11 & 1.37 & 1.41 & 2.94 & 1.00 & 1.31 & 1.49 \\
\hline $\mathrm{Eu}$ & 1.41 & 1.44 & 0.86 & 1.24 & 0.86 & 1.05 & 1.71 & 0.98 & 0.81 & 0.87 & 1.12 \\
\hline $\mathrm{Gd}$ & 1.89 & 1.58 & 1.08 & 1.11 & 1.12 & 1.48 & 1.54 & 2.68 & 1.07 & 1.28 & 1.48 \\
\hline $\mathrm{Tb}$ & 1.65 & 1.35 & 1.13 & 1.06 & 1.21 & 1.51 & 1.21 & 2.60 & 1.22 & 1.12 & 1.41 \\
\hline Dy & 1.43 & 1.33 & 1.16 & 1.16 & 1.36 & 1.44 & 1.31 & 1.86 & 1.33 & 1.22 & 1.36 \\
\hline $\mathrm{Er}$ & 1.20 & 1.39 & 1.28 & 1.16 & 1.17 & 1.36 & 1.16 & 0.90 & 1.27 & 1.22 & 1.21 \\
\hline $\mathrm{Tm}$ & 0.96 & 0.96 & 0.99 & 1.02 & 0.86 & 1.09 & 0.93 & 0.75 & 1.01 & 0.94 & 0.95 \\
\hline $\mathrm{Yb}$ & 0.96 & 1.06 & 1.13 & 1.13 & 0.94 & 1.25 & 0.96 & 0.83 & 1.19 & 1.09 & 1.05 \\
\hline $\mathrm{Lu}$ & 1.01 & 1.10 & 1.07 & 1.03 & 1.08 & 1.21 & 0.92 & 0.84 & 1.06 & 1.03 & 1.03 \\
\hline $\mathrm{Sc}$ & 0.62 & 1.1 & 0.62 & 0.73 & 0.78 & 0.59 & 0.56 & 0.3 & 0.61 & 0.24 & 0.62 \\
\hline Y & 0.60 & 1.02 & 0.69 & 0.80 & 0.55 & 0.82 & 0.38 & 0.52 & 0.65 & 0.44 & 0.75 \\
\hline
\end{tabular}

$\mathrm{Zn}$ is moderately abundant; its natural abundance and sources surpass its anthropogenic source. In this study, the trace elements were normalized to $\mathrm{Zn}$ at global average shale value and Ho for the REE. These elements were chosen as the reference elements because there is no known anthropogenic activity either within the vicinity of the sampling locations or in the long-distance which can be traceable as the source of these elements. Five contaminated categories are recognized on the basis of the Enrichment Factor: EF $<2$ (deficiency to minimal enrichment); $\mathrm{EF}=2$ to 5 (moderate enrichments); $\mathrm{EF}=5-20$ (significant enrichment); $\mathrm{EF}=20-40$ (very high enrichment) and EF > 40, is extremely high enrichment (Sutherland 2000). According to Zhang \& Liu (2002), EF values between 0.5 and 1.5 suggests that the element concerned may be derived entirely from crustal materials or natural weathering processes (geogenic). Values greater than 1.5 suggest a significant portion of the element has been supplied from non-natural (anthropogenic) sources. As the 


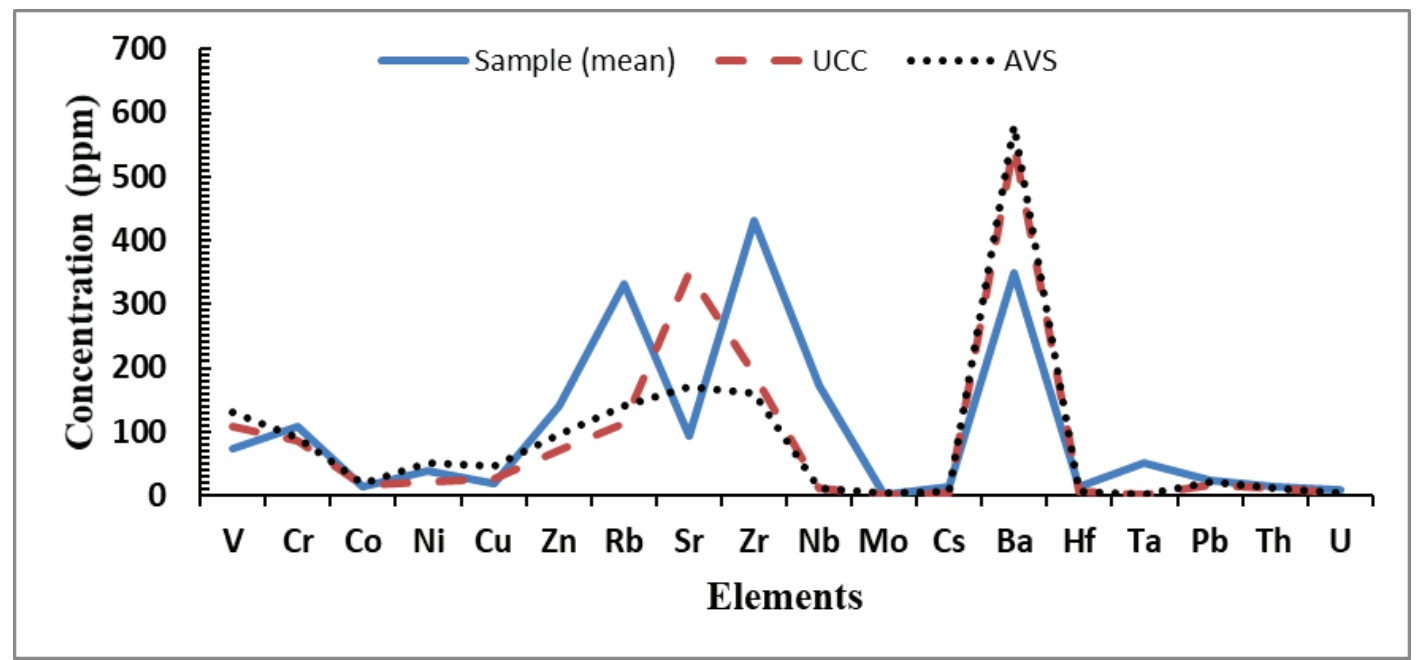

Fig. 4: Trace element concentration comparison between the mean of the samples studied, the upper continental crust and the average shale value.

EF values increase, the contributions of the anthropogenic origin also increase (Sutherland 2000).

The results of the enrichment factors of $\mathrm{V}, \mathrm{Cr}, \mathrm{Co}, \mathrm{Ni}$, $\mathrm{Cu}, \mathrm{Sr}, \mathrm{Mo}, \mathrm{Ba}, \mathrm{Pb}$, Th, La, Ce, Pr, Nd, Sm, Eu, Gd, Tb, Mo, Dy, Er, Tm, Yb, Lu Sc, and Y shows that these metals are deficient to minimal enrichment, because EF were $<$ 2. According to Zhang \& Liu (2002), they are therefore naturally derived from the stream sediment and geogenic sources resulting from weathering processes in the environment. The average $\mathrm{EF}$ values of $\mathrm{Rb}, \mathrm{Zr}, \mathrm{Hf}, \mathrm{U}$ and $\mathrm{Cs}$ indicated moderate enrichment, because they fall within the range of $2<\mathrm{EF}<5$. Only the $\mathrm{EF}$ of $\mathrm{Nb}$ has significant enrichment since the EF falls within the range $5<\mathrm{EF}<20$; and Ta has variable EF values from significant enrichment; very high enrichment to extremely high enrichment. Most of the EF values in the sediments were $<2$ and $2<\mathrm{EF}<5$, except the $\mathrm{Nb}$ and Ta. According to Sutherland (2000) and Zhang et al. (2007), the metals, therefore, originated from anthropogenic activities.

\section{Contamination Factor (CF) and Degree of Contamination $\left(\mathbf{C}_{\mathrm{d}}\right)$}

According to Demie (2015), the degree of contamination is aimed at providing a measure of the degree of overall contamination in surface layers of a particular sampling site. $\mathrm{CF}$ is calculated for individual elements using the formula proposed by Hakanson (1980): $\mathrm{CF}=\mathrm{C}_{\text {Element }} / \mathrm{C}_{\text {Background }}$, where $\mathrm{C}_{\text {Element }}$ is the concentration of elements at the con-

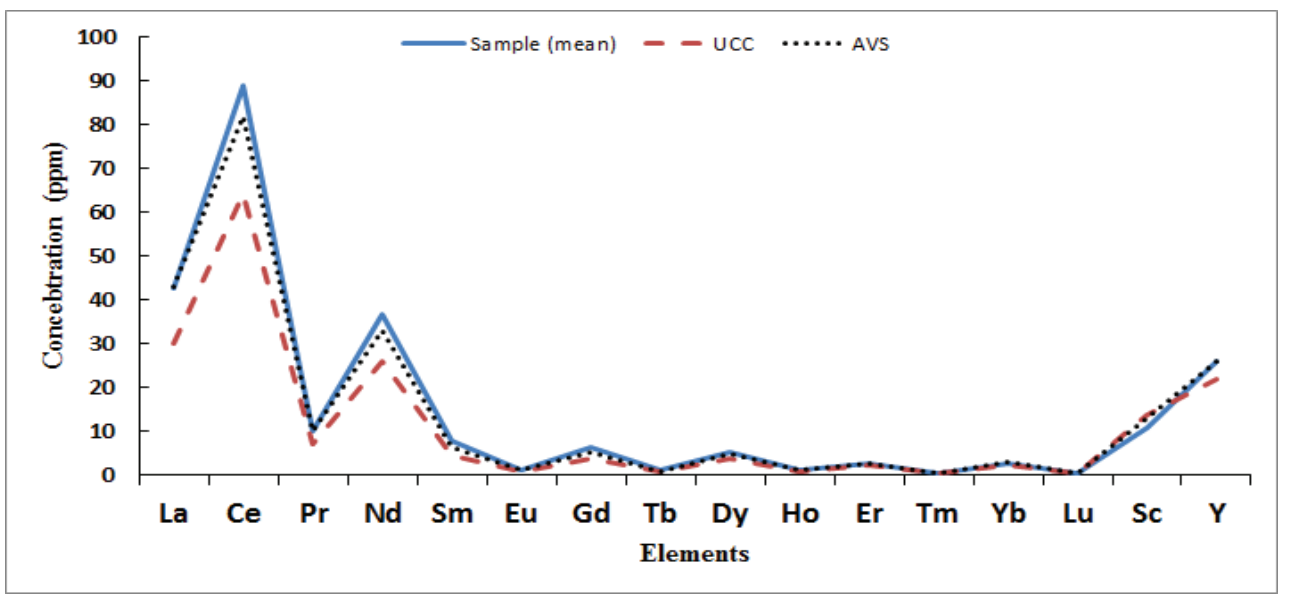

Fig. 5: REE concentration comparison between the mean of the samples studied, the upper continental crust and the average shale value. 


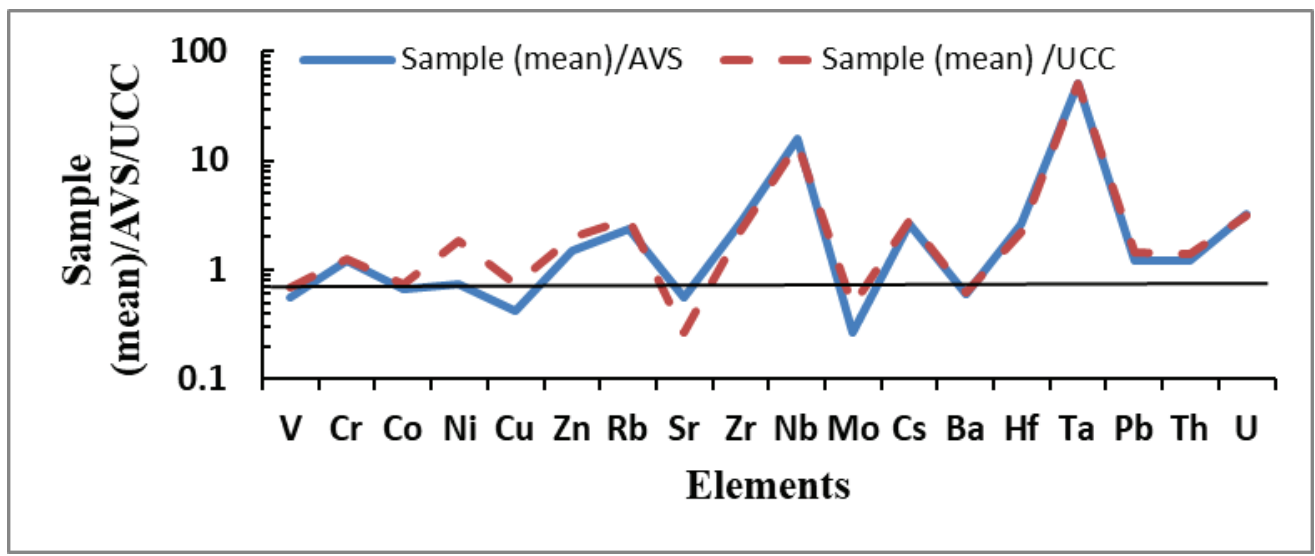

Fig. 6: AVS and UCC-normalized trace elements patterns for the stream sediments investigated.

taminated site and $\mathrm{C}_{\text {background }}$ is the background value of the same element.

Contamination Factor values of trace and rare earth elements in the Agbangudu stream sediments are presented in Table 3. Hakanson (1980) applied the CF under four categories: $\mathrm{CF}<1$ indicates low contamination; $1<\mathrm{CF}<3$ indicates moderate contamination; $3<\mathrm{CF}<6$ indicates considerable contamination; and $\mathrm{CF}>6$ indicates very high contamination. The results revealed that the $\mathrm{CF}$ of $\mathrm{V}, \mathrm{Co}, \mathrm{Zr}, \mathrm{Nb}, \mathrm{Mo}, \mathrm{Hf}$, $\mathrm{Th}, \mathrm{La}, \mathrm{Ce}, \mathrm{Pr}, \mathrm{Nd}, \mathrm{Sm}$ are Scare low; $\mathrm{CF}<1$. The $\mathrm{CF}$ of $\mathrm{Cu}$, $\mathrm{Zn}, \mathrm{Sr}, \mathrm{Ba}, \mathrm{Pb}, \mathrm{U}, \mathrm{Eu}, \mathrm{Gd}, \mathrm{Tb}, \mathrm{Dy}, \mathrm{Ho}, \mathrm{Er}, \mathrm{Tm}, \mathrm{Yb}, \mathrm{Lu}$ and $\mathrm{Y}$ all have moderate contamination. The $\mathrm{CF}$ of $\mathrm{Cr}, \mathrm{Ni}$, and $\mathrm{Rb}$ have considerable contamination; all of $\mathrm{Cs}$ and Ta locations have very high contamination because they have $\mathrm{CF}>6$. The high values for Cs and Ta may be due to geogenic and anthropogenic sources.

The degree of contamination $\left(\mathrm{C}_{\mathrm{d}}\right)$ is the sum of individual contamination factor of the pollutant (Hakanson 1980). This parameter is aimed at providing a measure of the degree of overall contamination in surface layers in particular sampling sites. The degree of contamination $\left(\mathrm{C}_{\mathrm{d}}\right)$ is computed by the equation by Hakanson (1980):

$$
\mathrm{C}_{\mathrm{d}}=\sum_{\mathrm{i}=1}^{\mathrm{n}} \mathrm{Cf}^{\mathrm{i}}
$$

Where, $\mathrm{Cf}$ is the contamination factor of each element; $\mathrm{n}$ is the number of elements under investigation. A modified form of the Hakanson (1980) equation proposed by Abrahim \& Parker (2008) for the calculation of the overall degree of contamination was utilized in this study and computed by the equation 3 :

$$
\mathrm{mC}_{\mathrm{d}}=\frac{\sum_{\mathrm{i}=1}^{\mathrm{n}} \mathrm{Cf}}{\mathrm{n}}
$$

Where, $\mathrm{mC}_{\mathrm{d}}$ is modified degree of contamination, $\mathrm{n}$ is the number of analysed element and $\mathrm{Cf}^{\mathrm{i}}$ is the contamination factor; the $\mathrm{mC}_{\mathrm{d}}$ data for the work are presented in Table 4 .

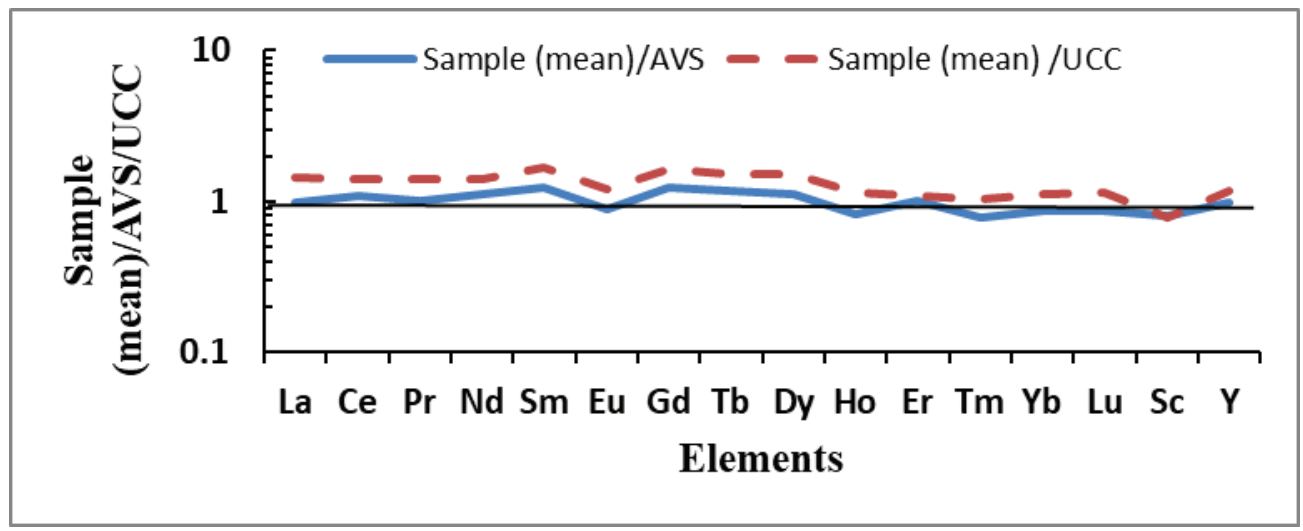

Fig. 7: AVS and UCC-normalized REE patterns for the stream sediments investigated. 
Table 3: Contamination factor $(\mathrm{CF})$ of trace and rare earth elements in the stream sediment.

\begin{tabular}{|c|c|c|c|c|c|c|c|c|c|c|c|}
\hline Elements & AGU-1 & AGU-2 & AGU-3 & AGU-4 & AGU-5 & AGU-6 & AGU-7 & AGU-8 & AGU-9 & AGU-10 & MEAN \\
\hline V & 0.99 & 1.31 & 0.80 & 0.80 & 0.54 & 0.66 & 0.72 & 0.71 & 1.34 & 0.62 & 0.85 \\
\hline $\mathrm{Cr}$ & 5.04 & 7.03 & 2.88 & 2.81 & 1.81 & 2.25 & 8.14 & 1.94 & 2.65 & 1.53 & 3.61 \\
\hline Co & 0.04 & 0.06 & 0.02 & 0.03 & 0.02 & 0.02 & 0.06 & 0.02 & 0.02 & 0.07 & 0.04 \\
\hline $\mathrm{Ni}$ & 5.09 & 8.34 & 3.32 & 3.12 & 1.83 & 2.40 & 5.50 & 1.83 & 2.86 & 1.34 & 3.56 \\
\hline $\mathrm{Cu}$ & 1.13 & 1.27 & 0.83 & 0.71 & 0.41 & 0.94 & 0.81 & 1.02 & 1.66 & 0.80 & 0.96 \\
\hline $\mathrm{Zn}$ & 2.18 & 1.60 & 1.91 & 1.42 & 1.13 & 1.73 & 1.69 & 3.07 & 2.55 & 3.60 & 2.09 \\
\hline $\mathrm{Rb}$ & 5.36 & 4.94 & 6.14 & 6.15 & 7.60 & 6.87 & 5.48 & 4.29 & 5.59 & 3.73 & 5.62 \\
\hline $\mathrm{Sr}$ & 1.92 & 1.54 & 0.89 & 1.33 & 0.99 & 0.96 & 2.39 & 1.58 & 0.48 & 0.36 & 1.24 \\
\hline $\mathrm{Zr}$ & 0.80 & 0.09 & 0.06 & 0.07 & 0.08 & 0.08 & 0.03 & 0.10 & 0.07 & 0.10 & 0.15 \\
\hline $\mathrm{Nb}$ & 0.73 & 0.40 & 0.41 & 0.81 & 0.47 & 0.67 & 0.39 & 1.04 & 0.46 & 0.76 & 0.61 \\
\hline Mo & 0.55 & 0.45 & 0.47 & 0.42 & 0.36 & 0.55 & 0.54 & 0.55 & 1.11 & 1.09 & 0.61 \\
\hline Cs & 45.89 & 52.96 & 61.36 & 40.79 & 36.61 & 41.79 & 57.32 & 28.18 & 64.39 & 32.68 & 46.20 \\
\hline $\mathrm{Ba}$ & 2.58 & 2.78 & 2.53 & 2.93 & 2.28 & 2.21 & 6.08 & 2.98 & 2.23 & 1.71 & 2.83 \\
\hline $\mathrm{Hf}$ & 0.57 & 0.57 & 0.39 & 0.41 & 0.49 & 0.49 & 0.19 & 0.79 & 0.45 & 0.61 & 0.50 \\
\hline $\mathrm{Ta}$ & 123.50 & 31.91 & 31.57 & 75.77 & 44.68 & 47.72 & 16.17 & 48.58 & 32.32 & 43.09 & 49.53 \\
\hline $\mathrm{Pb}$ & 1.33 & 1.39 & 1.72 & 1.77 & 1.43 & 1.68 & 2.07 & 2.05 & 1.48 & 1.09 & 1.60 \\
\hline $\mathrm{Th}$ & 0.33 & 0.31 & 0.17 & 0.19 & 0.26 & 0.27 & 0.16 & 1.16 & 0.31 & 0.39 & 0.35 \\
\hline $\mathrm{U}$ & 1.89 & 1.59 & 1.74 & 1.56 & 1.47 & 2.79 & 2.00 & 4.44 & 2.24 & 1.11 & 2.08 \\
\hline $\mathrm{La}$ & 0.64 & 0.73 & 0.38 & 0.46 & 0.55 & 0.44 & 0.32 & 1.11 & 0.47 & 0.63 & 0.57 \\
\hline $\mathrm{Ce}$ & 0.63 & 0.70 & 0.36 & 0.45 & 0.50 & 0.44 & 0.32 & 1.08 & 0.39 & 0.60 & 0.55 \\
\hline $\operatorname{Pr}$ & 0.73 & 0.81 & 0.42 & 0.48 & 0.60 & 0.50 & 0.33 & 1.27 & 0.48 & 0.73 & 0.63 \\
\hline $\mathrm{Nd}$ & 0.81 & 0.89 & 0.46 & 0.52 & 0.66 & 0.54 & 0.38 & 1.39 & 0.54 & 0.82 & 0.70 \\
\hline $\mathrm{Sm}$ & 1.19 & 1.17 & 0.61 & 0.62 & 0.88 & 0.79 & 0.45 & 2.00 & 0.72 & 1.00 & 0.94 \\
\hline $\mathrm{Eu}$ & 1.88 & 2.47 & 1.22 & 1.51 & 1.57 & 1.38 & 1.25 & 1.53 & 1.35 & 1.53 & 1.57 \\
\hline $\mathrm{Gd}$ & 1.28 & 1.38 & 0.77 & 0.69 & 1.04 & 0.99 & 0.57 & 2.12 & 0.91 & 1.14 & 1.09 \\
\hline $\mathrm{Tb}$ & 1.64 & 1.72 & 1.19 & 0.97 & 1.64 & 1.48 & 0.66 & 3.02 & 1.52 & 1.45 & 1.53 \\
\hline Dy & 1.56 & 1.87 & 1.34 & 1.16 & 2.02 & 1.55 & 0.78 & 2.36 & 1.81 & 1.73 & 1.62 \\
\hline Ho & 0.94 & 1.21 & 1.00 & 0.87 & 1.29 & 0.93 & 0.52 & 1.10 & 1.18 & 1.24 & 1.03 \\
\hline $\mathrm{Er}$ & 1.21 & 1.80 & 1.36 & 1.07 & 1.61 & 1.36 & 0.64 & 1.06 & 1.60 & 1.61 & 1.33 \\
\hline $\mathrm{Tm}$ & 1.14 & 1.46 & 1.25 & 1.11 & 1.39 & 1.29 & 0.61 & 1.04 & 1.50 & 1.46 & 1.23 \\
\hline $\mathrm{Yb}$ & 0.99 & 1.41 & 1.23 & 1.07 & 1.34 & 1.28 & 0.54 & 1.00 & 1.53 & 1.48 & 1.19 \\
\hline $\mathrm{Lu}$ & 1.03 & 1.45 & 1.16 & 0.97 & 1.52 & 1.23 & 0.52 & 1.00 & 1.35 & 1.39 & 1.16 \\
\hline $\mathrm{Sc}$ & 0.91 & 1.91 & 0.79 & 0.69 & 0.60 & 0.68 & 0.64 & 0.62 & 1.05 & 0.59 & 0.85 \\
\hline $\mathrm{Y}$ & 1.00 & 1.25 & 1.00 & 0.86 & 1.34 & 1.08 & 0.49 & 1.21 & 1.26 & 1.20 & 1.07 \\
\hline
\end{tabular}

Abrahim \& Parker (2008) proposed the following classes for the modified degree of contamination: $\mathrm{mCd}<1.5$, nil to very low degree of contamination; $1.5 \leq \mathrm{mCd}<2$, low degree of contamination; $2 \leq \mathrm{mCd}<4$, moderate degree of contamination; $4 \leq \mathrm{mCd}<8$, high degree of contamination; $8 \leq \mathrm{mCd}<16$, a very high degree of contamination; $16 \leq \mathrm{mCd}<32$, an extremely high degree of contamination and $\mathrm{mCd} \geq 32$ means the ultra-high degree of contamination. Results from this study classified the level of the metal as non-contaminated to very low contamination, while $\mathrm{Ta}$ and $\mathrm{Nb}$ showed a high degree of contamination.

\section{Pollution Load Index (PLI)}

The Pollution Load Index (PLI) was developed by Tomlin- 
son et al. (1980) to compare pollution levels between sites and propose a necessary line of action. According to Priju \& Narayana (2006), PLI represents the number of times by which the element concentrations in the sediments exceeds the background concentration, and gives a summative indication of the overall level of element toxicity at a particular sample site. The PLI was computed based on the method proposed by Tomlinson et al. (1980). The PLI of the area was evaluated by obtaining the n-root from the $\mathrm{n}-\mathrm{CFs}$ that were obtained for all the elements. This parameter is expressed as:

$$
\mathrm{PLI}=(\mathrm{CF} 1 \times \mathrm{CF} 2 \times \mathrm{CF} 3 \times \ldots \ldots \ldots . . \mathrm{CFn}) 1 / \mathrm{n}
$$

Where, $\mathrm{n}$ is the number of elements and $\mathrm{CF}$ is the contamination factor, the PLI values are shown in Table 4. According to Tomlinson et al. (1980), a Pollution Load Index $(\mathrm{PLI})<1$ denote perfection; PLI $=1$ present that only baseline levels of pollutants are present and PLI $>1$ would indicate deterioration of site quality. The results obtained put the PLI values at approximately 1 , which indicates only baseline levels of metals. However, PLI data without Ta and Cs denotes perfection. Likuku et al. (2013) proposed that a PLI value of $\geq 1$ indicates an immediate intervention to ameliorate pollution; $0.5 \leq \mathrm{PLI}<1$ suggests that more detailed study is needed to monitor the site, whilst a value of $<0.5$ indicates that there is no need for drastic rectification measures to be taken.

\section{Geoaccumulation Index (Igeo)}

Geoaccumulation index (Igeo) was first introduced by Muller (1969) to compare the present-day heavy metal concentration with the pre-civilized background values. According to Singh et al. (1997), Igeo can be used to quantify the degree of contamination in stream sediments. Afkhami et al. (2013) affirmed that Igeo values can be used effectively and more meaningfully in explicating sediment quality. The Igeo of the elements was calculated by computing the base $2 \mathrm{log}$ of the measured total concentration of the element over its background concentration using this equation:

$$
\text { Igeo }=\log _{2}[\mathrm{Cn} / 1.5 \times \mathrm{Bn}]
$$

Where, $\mathrm{Cn}$ is the measured concentration of the stream sample for the element (n), and $\mathrm{Bn}$ is the background value of the element (n). The correction factor; 1.5 was used to account for possible variations in background data due to lithogenic effects. Muller (1969) proposed seven descriptive classes for increasing Igeo values: Igeo $>5$ indicates extremely contaminated; $4<$ Igeo $<5$ indicates strongly to extremely contaminated; $3<$ Igeo $<4$ indicates strongly contaminated; $2<$ Igeo $<3$ indicates moderately to strongly contaminated; $1<$ Igeo $<2$ indicates moderately contaminated; $0<$ Igeo $<1$ indicates uncontaminated to moderately contaminated; and Igeo $=0$ indicates uncontaminated. The geoaccumulation index (Igeo) of the elements in the stream sediments is shown in Table 5. All the elements showed uncontaminated to moderately contaminated, except for $\mathrm{Cs}$ and $\mathrm{Ta}$ with strongly to extremely contaminated status.

\section{Rare Earth Element}

The chondrite normalisation curves (Fig. 8) show enrichment in light rare earth elements (LREE) and depletion of heavy rare earth elements (HREE). The Average Shale Value (AVS) and the Upper Continental Crust (UCC) normalized REE distribution patterns of the stream sediments are given in Figs. 9A and 9B indicating a moderate enrichment in LREE. All the samples show a $(\mathrm{La} / \mathrm{Yb}) \mathrm{n}>1$, meaning an enrichment in LREE in the stream sediments (Table 6). These observations show that the REEs are mainly derived from intermediate and felsic rocks (McLennan 1989). Flat REE distribution

Table 4: Modified Degree of Contamination (mCd) Pollution Load Index (PLI) of the trace and rare earth elements in the stream sediments.

\begin{tabular}{|lllll|}
\hline Sample ID & mCd & PLI & mCd* ${ }^{*}$ & 1.03 \\
\hline AGU-1 & 6.40 & 1.32 & 1.42 & 1.62 \\
AGU-2 & 4.12 & 1.40 & 1.14 & 0.79 \\
AGU-3 & 3.88 & 1.00 & 1.12 & 0.79 \\
AGU-4 & 4.55 & 1.02 & 1.17 & 0.82 \\
AGU-5 & 3.56 & 1.03 & 1.18 & 0.85 \\
AGU-6 & 3.82 & 1.07 & 1.33 & 0.69 \\
AGU-7 & 3.49 & 0.86 & 1.48 & 1.17 \\
AGU-8 & 3.74 & 1.43 & 1.27 & 0.93 \\
AGU-9 & 4.11 & 1.16 & 1.08 & 0.84 \\
AGU-10 & 3.31 & 1.05 & & \\
\hline
\end{tabular}

$\mathrm{mCd}^{*}$ and PLI* $=$ without Ta and Cs values 
Table 5: Geoaccumulation Index (Igeo) of trace and rare earth elements in the stream sediment.

\begin{tabular}{|c|c|c|c|c|c|c|c|c|c|c|c|}
\hline Elements & AG-1 & AG-2 & AG-3 & AG-4 & AG-5 & AG-6 & AG-7 & AG-8 & AG-9 & AG-10 & Mean \\
\hline V & -0.60 & -0.20 & -0.91 & -0.91 & -1.47 & -1.19 & -1.05 & -1.08 & -0.17 & -1.29 & -0.89 \\
\hline $\mathrm{Cr}$ & 0.22 & 2.23 & 0.94 & 0.90 & 0.27 & 0.58 & 2.44 & 0.37 & 0.82 & 0.02 & 0.88 \\
\hline Co & -5.29 & -4.71 & -5.96 & -5.71 & -6.55 & -6.13 & -4.75 & -6.10 & -6.16 & -7.01 & -5.84 \\
\hline $\mathrm{Ni}$ & 1.98 & 2.48 & 1.14 & 1.06 & 0.29 & 0.68 & 1.87 & 0.29 & 0.93 & -0.16 & 1.06 \\
\hline $\mathrm{Cu}$ & -0.41 & -0.24 & -0.68 & -1.09 & -1.87 & -0.67 & -0.88 & -0.56 & 0.15 & -0.92 & -0.72 \\
\hline $\mathrm{Zn}$ & 0.54 & 0.10 & 0.35 & -0.09 & -0.41 & 0.20 & 0.17 & 1.03 & 0.76 & 1.26 & 0.39 \\
\hline $\mathrm{Rb}$ & 1.84 & 1.72 & 2.03 & 2.04 & 2.34 & 2.20 & 1.87 & 1.52 & 1.90 & 1.32 & 1.88 \\
\hline $\mathrm{Sr}$ & 0.36 & 0.04 & -0.76 & -0.17 & -0.60 & -0.65 & 0.67 & 0.07 & -1.66 & -2.05 & -0.48 \\
\hline $\mathrm{Zr}$ & -4.16 & -4.00 & -4.61 & -4.43 & -4.26 & -4.25 & -5.62 & -3.89 & -4.36 & -3.85 & -4.34 \\
\hline $\mathrm{Nb}$ & -1.04 & -1.90 & -1.88 & -0.90 & -1.67 & -1.83 & -1.96 & -0.52 & -1.72 & -0.97 & -1.44 \\
\hline Мо & -1.45 & -1.74 & -1.67 & -1.83 & -2.07 & -1.45 & -1.49 & -1.45 & -0.43 & -2.01 & -1.56 \\
\hline Cs & 4.94 & 5.14 & 5.35 & 4.77 & 4.61 & 4.80 & 5.26 & 4.23 & 5.42 & 4.45 & 4.90 \\
\hline $\mathrm{Ba}$ & 0.78 & 0.89 & 0.75 & 0.96 & 0.60 & 0.56 & 2.02 & 0.99 & 0.57 & 0.19 & 0.83 \\
\hline $\mathrm{Hf}$ & -1.41 & -1.41 & -1.93 & -1.86 & -1.62 & -1.61 & -2.96 & -0.93 & -1.73 & -1.31 & -1.68 \\
\hline $\mathrm{Ta}$ & 6.36 & 4.41 & 4.40 & 5.66 & 4.90 & 4.99 & 3.43 & 5.02 & 4.43 & 4.84 & 4.84 \\
\hline $\mathrm{Pb}$ & -0.17 & -0.11 & 0.20 & 0.24 & -0.07 & 0.16 & 0.47 & 0.45 & -0.02 & -0.46 & 0.07 \\
\hline Th & -2.19 & -2.27 & -3.12 & -2.99 & -2.51 & -2.48 & -3.23 & -0.38 & -2.29 & -1.94 & -2.34 \\
\hline $\mathrm{U}$ & 0.33 & 0.08 & 0.21 & 0.06 & -0.03 & 0.89 & 0.42 & 1.57 & 0.58 & -0.44 & 0.37 \\
\hline $\mathrm{La}$ & -1.24 & -1.04 & -2.00 & -1.71 & -1.46 & -1.75 & -2.22 & -0.43 & -1.66 & -1.24 & -1.48 \\
\hline $\mathrm{Ce}$ & -1.26 & -1.11 & -2.06 & -1.75 & -1.60 & -1.75 & -2.24 & -0.48 & -1.94 & -1.33 & -1.55 \\
\hline $\operatorname{Pr}$ & -1.04 & -0.89 & -1.84 & -1.65 & -1.33 & -1.60 & -2.17 & -0.24 & -1.64 & -1.04 & -1.34 \\
\hline $\mathrm{Nd}$ & -0.89 & -0.76 & -1.71 & -1.54 & -1.19 & -1.47 & -1.99 & -0.11 & -1.46 & -0.87 & -1.20 \\
\hline $\mathrm{Sm}$ & -0.34 & -0.35 & -1.29 & -1.27 & -0.77 & -0.93 & -1.74 & 0.41 & -1.05 & -0.59 & -0.79 \\
\hline $\mathrm{Eu}$ & 0.33 & 0.72 & -0.30 & 0.01 & 0.07 & -0.12 & -0.26 & 0.03 & -0.15 & 0.03 & 0.04 \\
\hline Gd & -0.23 & -0.12 & -0.96 & -1.13 & -0.53 & -0.60 & -1.40 & 0.50 & -0.73 & -0.40 & -0.56 \\
\hline $\mathrm{Tb}$ & 0.13 & 0.20 & -0.34 & -0.63 & 0.13 & -0.02 & -1.19 & 1.01 & 0.01 & -0.05 & -0.07 \\
\hline Dy & 0.05 & 0.31 & -0.17 & -0.38 & 0.43 & 0.04 & -0.94 & 0.65 & 0.27 & 0.21 & 0.05 \\
\hline Ho & -0.67 & -0.31 & -0.58 & -0.79 & -0.22 & -0.69 & -1.54 & -0.45 & -0.35 & -0.28 & -0.59 \\
\hline $\mathrm{Er}$ & -0.31 & 0.27 & -0.14 & -0.49 & 0.10 & -0.15 & -1.23 & -0.50 & 0.09 & 0.10 & -0.23 \\
\hline $\mathrm{Tm}$ & -0.39 & -0.03 & -0.26 & -0.44 & -0.11 & -0.22 & -1.30 & -0.53 & 0.00 & -0.03 & -0.33 \\
\hline $\mathrm{Yb}$ & -0.60 & -0.09 & -0.28 & -0.48 & -0.17 & -0.23 & -1.47 & -0.59 & 0.03 & -0.02 & -0.39 \\
\hline $\mathrm{Lu}$ & -0.54 & -0.05 & -0.37 & -0.63 & 0.02 & -0.29 & -1.54 & -0.58 & -0.15 & -0.11 & -0.42 \\
\hline $\mathrm{Sc}$ & -0.72 & -0.33 & -0.93 & -1.12 & -1.33 & -1.14 & -1.24 & -1.29 & -0.52 & -1.34 & -1.00 \\
\hline Y & -0.59 & -0.26 & -0.58 & -0.80 & -0.16 & -0.47 & -1.61 & -0.31 & -0.25 & -0.33 & -0.54 \\
\hline
\end{tabular}

commonly observed from river sediments is due to the average upper crustal surface composition and source rocks (Sholkovitz 1993). Also, according to Sholkovitz (1993), the mixing and homogenizing effects of sedimentary processes will produce uniform REE pattern which signifies the abundance in the upper continental crust. Enrichment of LREE reflects the intense silicate weathering of crustal materials and a subsequent increase in LREEs in detrital. The LREE/ HREE ratios for the stream sediments range from 6.7 to 12.9 with an average of 9.13 (Table 5), which is slightly more than the upper crustal ratio and is equal to average shale ratio. $(\mathrm{La} / \mathrm{Yb}) \mathrm{n}$ ratios range between 7.89 to 28.93 with a mean ratio of 13.22 and that indicates very high erosional rates, which suggests that La was removed from the crustal 


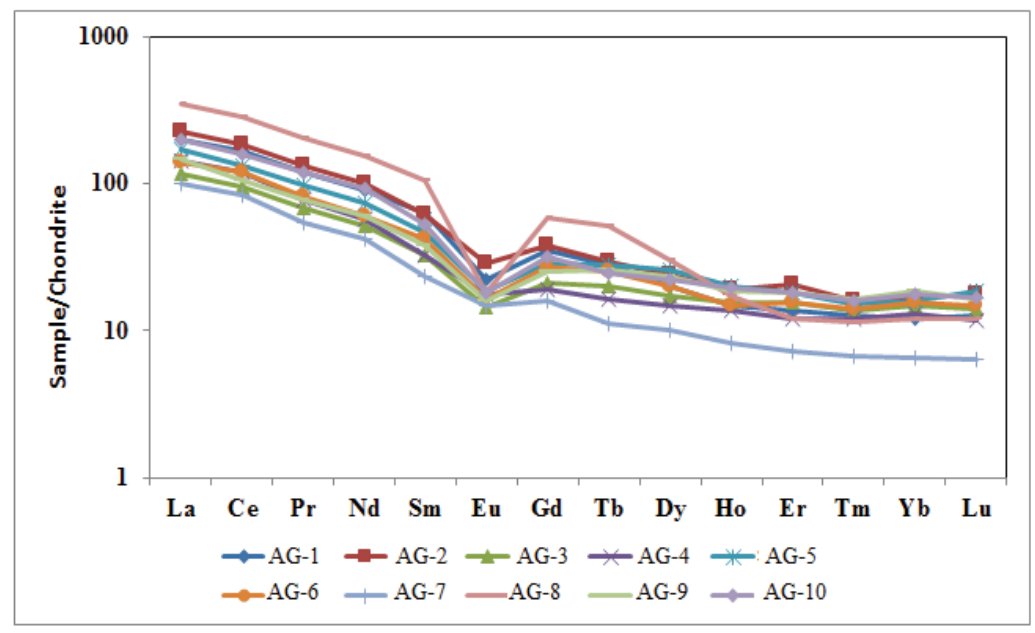

Fig. 8: REE composition of the stream sediments normalized to chondrites based on Taylor \& McLennan (1985).

source through the weathering process, then transported and deposited by the streams.

According to McLennan (1988), generally, the La/Yb ratio is found to be very low in sediments rich in coarse size fractions and felsic minerals. Ramesh et al. (2000) opined that physical weathering is predominant in fine-grained sediments, which suggests that REEs fractionation took place in the stream.Y exhibits a moderate positive correlation with the LREEs (0.50), suggesting a partial association with detrital. Variation in $\mathrm{Ce}$ anomalies is indicative of terrigenous input, depositional environment and diagenetic conditions (Toyoda et al. 1990). Ce/Ce* $>1$ and $<1$ indicates positive (reducing environment) and negative (toxic environment) anomalies, respectively (Toyoda et al. 1990). Ce/Ce* ratio range of 3.14 to 3.70 with a mean ratio of 3.47 suggests minimal terrigenous input in a reducing environment.

All the $\mathrm{Eu} / \mathrm{Eu} *$ ratios for the stream sediments are $<1$ (Table 6), implying that the origin of this element $(\mathrm{Eu})$ is rich in feldspar source, contributing to a positive anomaly in the stream. According to Burg et al. (1984) and Gansser et al. (1983), this may also be due to the weathering of granite and granitic gneiss in the source region.

\section{Cluster Analysis}

For a more detailed comparison of the analysed metals and oxides in the stream sediments, cluster analysis by Ward (1963) method was performed and a dendrogram illustrating the results were presented in Figs. 10 to 12. This was employed in the study to see a possible association of the elements and to determine the similarities as regards the levels of the analysed metals and oxides. The distance cluster represents the degree of association between the elements and oxides. The lower the values on the distance cluster the more significant the association. Despite the common occurrence of these elements and oxides, their overall patterns were much different as revealed by the
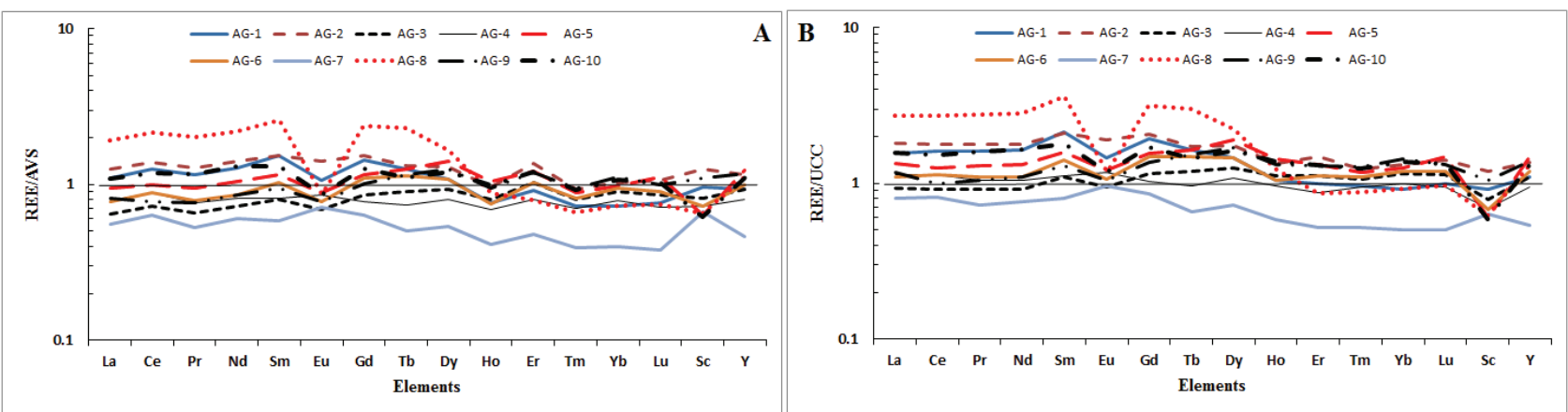

Fig. 9: (A) The average shale value (AVS) and (B) upper continental crust (UCC) normalised REE distribution pattern of the stream sediments. 
cluster analysis. In Fig. 10, three distinct clusters can be identified; Cluster 1 contained Y, La, Nd, SiO2 and Ce; indicating a close relationship between $\mathrm{La}$ and $\mathrm{Nd}$, while a possible relationship was also exhibited between $\mathrm{SiO} 2$ and Ce. This was similar to the enrichment factor of the metals, where the results revealed that the metals were naturally derived and geogenic sources resulting from weathering processes in the sediments. Clusters 2 showed possible interaction between most rare-earth elements and oxides such as $\mathrm{CrO}_{2}, \mathrm{MnO}, \mathrm{P}_{2} \mathrm{O}_{5}, \mathrm{CaO}, \mathrm{TiO}_{2}, \mathrm{Fe}_{2} \mathrm{O}_{3}, \mathrm{~K}_{2} \mathrm{O}, \mathrm{Na}_{2} \mathrm{O}$ and $\mathrm{MgO}$, while Cluster 3 reflected the strong relationship of $\mathrm{Al}_{2} \mathrm{O}_{3}$ with $\mathrm{Sc}, \mathrm{Gd}$, Dy, Pr and $\mathrm{Sm}$ at a particular level. These elements may probably be affected by a similar factor or originate from the same natural parents of the sediments. In Fig. 11, three clusters were also formed. Cluster 1 showed a close relationship between $\mathrm{Zr}, \mathrm{Rb}$ and $\mathrm{Ba}$. Cluster 2 showed that majority of the trace elements and oxides were found to be closely associated with other elements in natural materials, especially with those that formed a distinct cluster at a distance cluster of below 200, while Cluster 3 showed a close association between $\mathrm{Zn}, \mathrm{Nb}$, $\mathrm{Cr}, \mathrm{Sr}, \mathrm{Ta}, \mathrm{V}$ and $\mathrm{SiO}_{2}$. The association may reflect possible

Table 6: Distribution of $\Sigma$ LREE, $\Sigma$ HREE, $\Sigma$ REE, $\Sigma$ LREE/ $\Sigma$ HREE and ratios and anomalies of some rare earth elements in the stream sediments.

\begin{tabular}{|c|c|c|c|c|c|c|c|c|c|}
\hline Sample ID & $\Sigma$ LREE & $\Sigma$ HREE & $\Sigma$ REE & 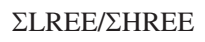 & $\mathrm{La} / \mathrm{Yb}$ & $\mathrm{La} / \mathrm{Sm}$ & $\mathrm{Gd} / \mathrm{Yb}$ & $\mathrm{Eu} / \mathrm{Eu}^{*}$ & $\mathrm{Ce} / \mathrm{Ce}^{*}$ \\
\hline AG-1 & 212.57 & 20.51 & 269.59 & 10.36 & 16.65 & 3.18 & 2.98 & 0.47 & 3.51 \\
\hline AG-2 & 236.05 & 24.96 & 307.43 & 9.46 & 13.39 & 3.68 & 2.25 & 0.6 & 3.48 \\
\hline AG-3 & 121.9 & 17.05 & 173.94 & 7.15 & 7.89 & 3.63 & 1.44 & 0.54 & 3.48 \\
\hline AG-4 & 146.26 & 14.93 & 191.45 & 9.8 & 11.06 & 4.36 & 1.47 & 0.71 & 3.66 \\
\hline AG-5 & 172.04 & 22.44 & 234.97 & 7.67 & 10.58 & 3.68 & 1.79 & 0.5 & 3.33 \\
\hline AG-6 & 147.91 & 19.32 & 202.63 & 7.66 & 9.03 & 3.34 & 1.78 & 0.48 & 3.62 \\
\hline AG-7 & 104.1 & 10.17 & 134.83 & 10.24 & 15.47 & 4.27 & 2.42 & 0.76 & 3.7 \\
\hline AG-8 & 366.02 & 28.37 & 431.95 & 12.9 & 28.93 & 3.3 & 4.89 & 0.23 & 3.47 \\
\hline AG-9 & 140.74 & 21 & 206.43 & 6.7 & 8.04 & 3.88 & 1.36 & 0.51 & 3.14 \\
\hline AG-10 & 206.96 & 22.09 & 266.06 & 9.37 & 11.14 & 3.78 & 1.77 & 0.44 & 3.36 \\
\hline MEAN & 185.46 & 20.08 & 241.93 & 9.13 & 13.22 & 3.71 & 2.22 & 0.52 & 3.47 \\
\hline
\end{tabular}

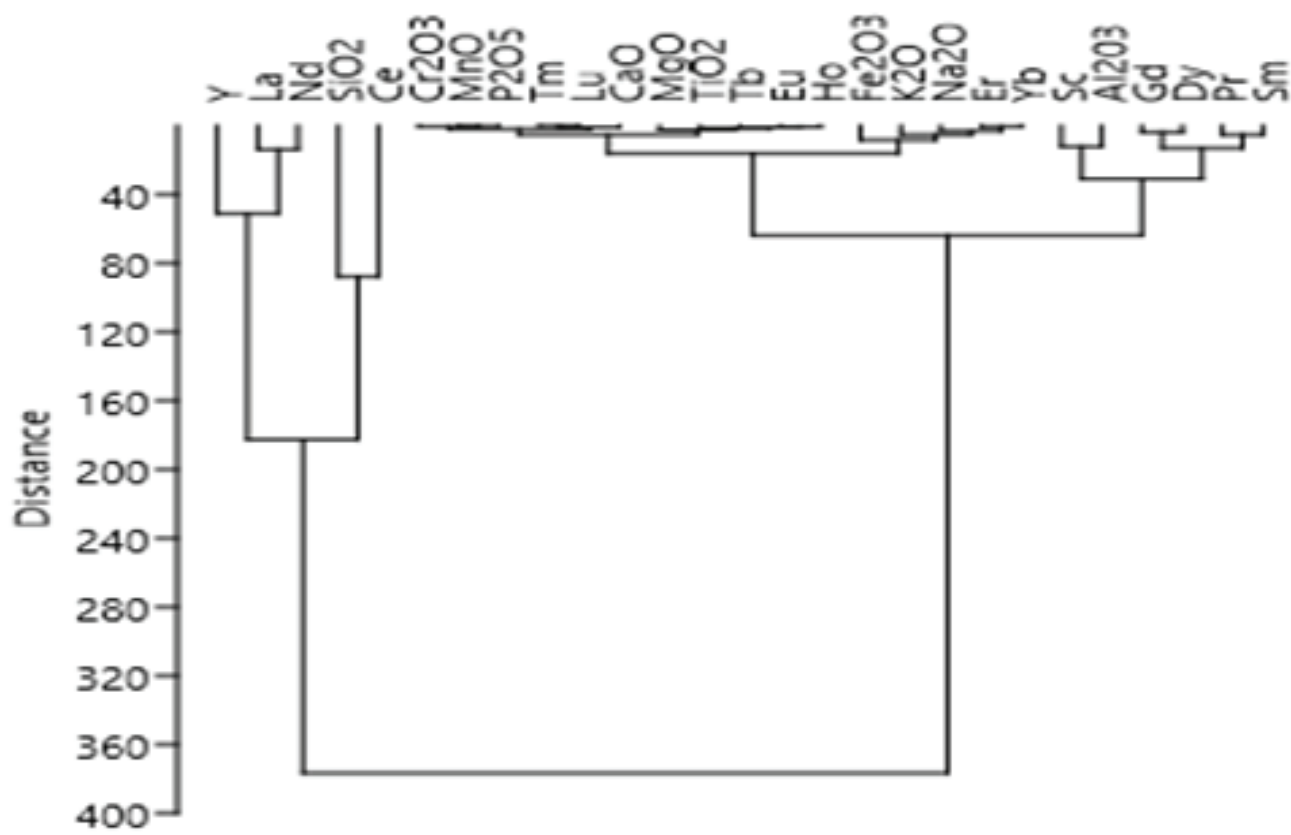

Fig.10: Dendrogram derived from the hierarchical cluster analysis of rare-earth elements and major oxides in the analysed stream sediments. 
Table 7: Matrix of the principal analysis loadings of major oxides and trace elements in the stream sediments.

\begin{tabular}{|c|c|c|c|c|c|}
\hline Oxides and elements & $\mathrm{PC} 1$ & $\mathrm{PC} 2$ & PC3 & $\mathrm{PC} 4$ & PC5 \\
\hline $\mathrm{SiO}_{2}$ & -0.017 & 0.011 & -0.046 & -0.009 & -0.04 \\
\hline $\mathrm{Al}_{2} \mathrm{O}_{3}$ & 0.005 & -0.015 & 0.01 & 0.005 & 0.016 \\
\hline $\mathrm{Fe}_{2} \mathrm{O}_{3}$ & 0.004 & 0.006 & 0.016 & -0.007 & 0.007 \\
\hline $\mathrm{CaO}$ & 0.0005 & 0.0008 & 0.003 & 0.004 & 0.003 \\
\hline $\mathrm{MgO}$ & 0.002 & 0.002 & 0.008 & 0.004 & 0.004 \\
\hline $\mathrm{MnO}$ & 0.0003 & 0.0004 & -0.0002 & -0.0001 & -0.0003 \\
\hline $\mathrm{K}_{2} \mathrm{O}$ & 0.002 & -0.003 & -0.006 & 0.006 & -0.009 \\
\hline $\mathrm{Na}_{2} \mathrm{O}$ & 0.001 & -0.002 & -0.001 & 0.0006 & 0.002 \\
\hline $\mathrm{P}_{2} \mathrm{O}_{5}$ & 0.0006 & 0.0006 & 0.0005 & 0.0003 & 0.0001 \\
\hline $\mathrm{TiO}_{2}$ & -0.0001 & 0.002 & 0.003 & -0.002 & 0.002 \\
\hline $\mathrm{Cr}_{2} \mathrm{O}_{3}$ & -5.70 E-38 & $-3.00 \mathrm{E}-37$ & $-3.50 \mathrm{E}-36$ & $7.90 \mathrm{E}-36$ & $-1,0 \mathrm{E}-37$ \\
\hline V & -0.0008 & 0.017 & 0.262 & -0.066 & 0.218 \\
\hline $\mathrm{Cr}$ & 0.274 & 0.19 & 0.607 & 0.125 & 0.169 \\
\hline Co & 0.025 & 0.02 & 0.062 & 0.027 & 0.012 \\
\hline $\mathrm{Ni}$ & 0.053 & 0.046 & 0.283 & 0.096 & 0.122 \\
\hline $\mathrm{Cu}$ & -0.004 & 0.015 & 0.046 & -0.035 & 0.064 \\
\hline $\mathrm{Zn}$ & -0.127 & 0.33 & -0.179 & -0.469 & 0.189 \\
\hline $\mathrm{Rb}$ & 0.065 & -0.601 & -0.105 & 0.425 & -0.225 \\
\hline $\mathrm{Sr}$ & 0.181 & 0.188 & 0.066 & 0.443 & 0.127 \\
\hline $\mathrm{Zr}$ & -0.552 & 0.435 & 0.266 & 0.318 & -0.496 \\
\hline $\mathrm{Nb}$ & -0.154 & 0.325 & -0.554 & 0.39 & 0.232 \\
\hline Mo & $3.70 \mathrm{E}-05$ & -0.0002 & 0.0002 & -0.002 & 0.003 \\
\hline Cs & 0.009 & -0.012 & 0.024 & -0.027 & 0.031 \\
\hline $\mathrm{Ba}$ & 0.732 & 0.39 & -0.207 & 0.061 & -0.339 \\
\hline $\mathrm{Hf}$ & -0.017 & 0.019 & -0.0006 & 0.017 & -0.017 \\
\hline $\mathrm{Ta}$ & -0.048 & 0.026 & -0.024 & 0.333 & 0.613 \\
\hline $\mathrm{Pb}$ & 0.015 & 0.006 & -0.037 & 0.013 & -0.023 \\
\hline Th & -0.022 & 0.074 & -0.056 & 0.031 & -0.09 \\
\hline $\mathrm{U}$ & -0.001 & 0.015 & -0.026 & 0.015 & -0.022 \\
\hline
\end{tabular}

natural parent materials, or inputs of some anthropogenic activities and/or natural geochemical system.

A distance cluster of about 160 was used for trace elements and rare-earth metals analysis (Fig. 12). Cluster 1 showed a close association between $\mathrm{Cr}, \mathrm{Sr}$ and Ce. Cluster 2 is in three groups, with $\mathrm{Ta}, \mathrm{La}, \mathrm{Ni}$ and $\mathrm{Nd}$ in group 1, while the second group contained $\mathrm{Cu}, \mathrm{Pb}, \mathrm{Y}$ and Th and combines with the other group which contain most elements. This suggested that the association between these elements is very significant and further indicates that the elements probably originated from natural materials or natural geochemical system and/or possibly associated with inputs from anthropogenic activities.
The clustering of the metals also reaffirms the confirmation of EF results, which shows that the metals are majorly from natural and geogenic sources. A distinct relationship was observed between $\mathrm{Zn}$ and $\mathrm{Nb}$, while $\mathrm{Rb}, \mathrm{Ba}$ and $\mathrm{Zr}$ also formed a distinct cluster at about 720 Euclidean distance. $\mathrm{Rb}$ and $\mathrm{Zr}$ indicated moderate enrichment from the EF, this was also affirmed from the close association of the metals.

\section{Principal Component Analysis}

The results of principal component analysis (PCA) of the metals and oxides concentrations in the stream sediments are shown in Tables 7-9. Five principal components were em- 


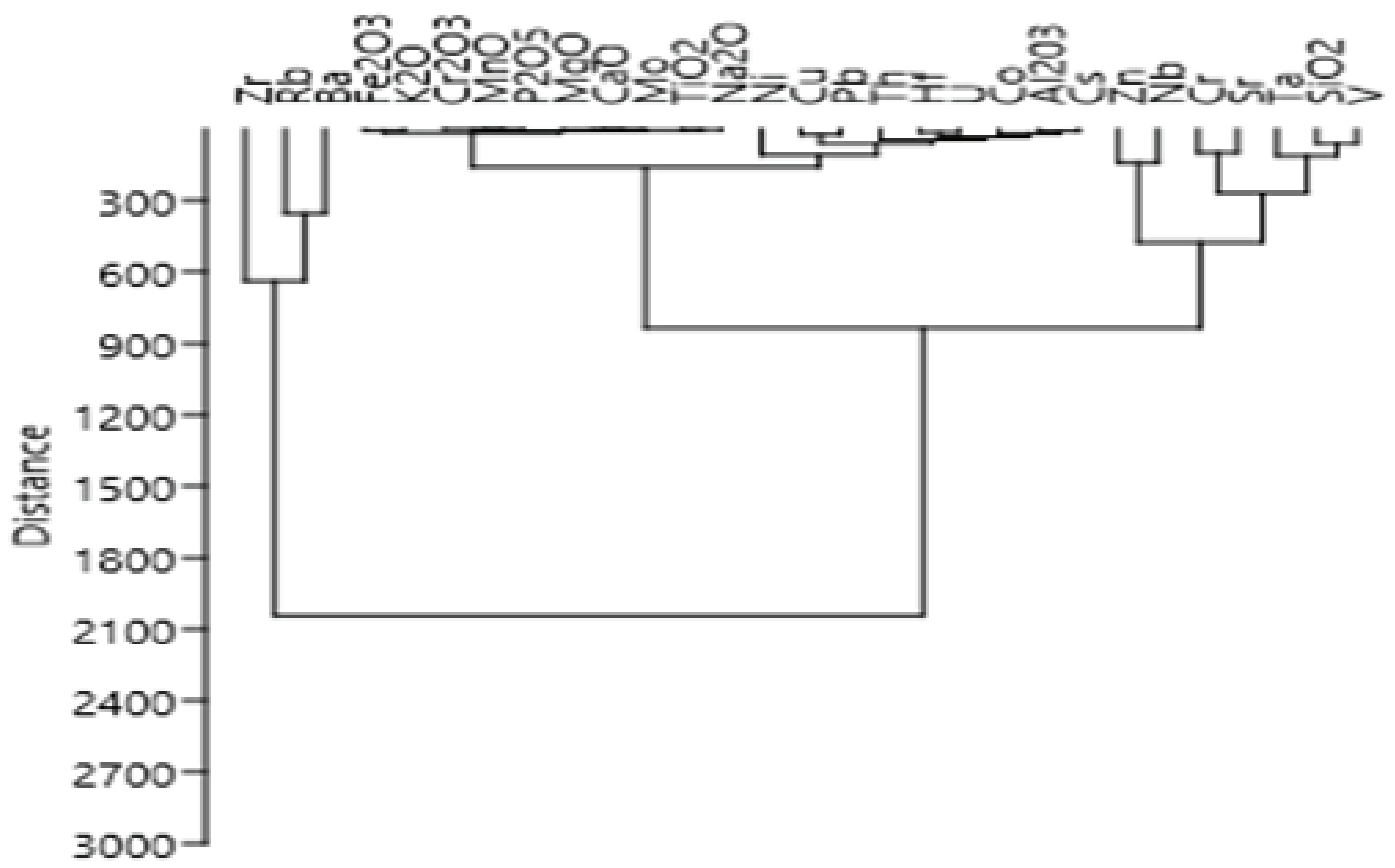

Fig. 11: Dendrogram derived from the hierarchical cluster analysis of trace elements and major oxides in the analysed stream sediments.

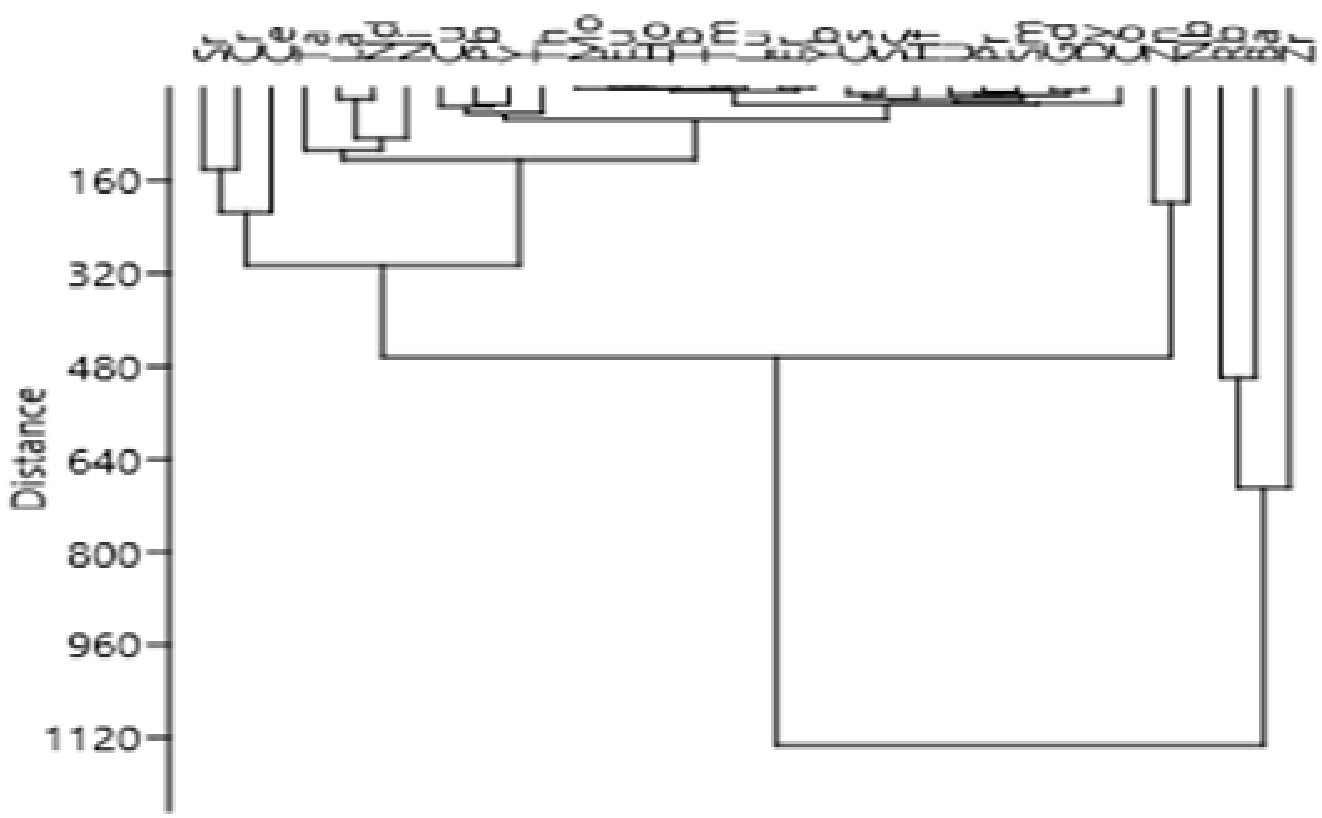

Fig. 12: Dendrogram derived from the hierarchical cluster analysis of trace elements and rare-earths in the analysed stream sediments.

ployed, PC1 accounted for 64.5 to $95.9 \%$ of the total variance in three interactions. Table 7 showed the factor loadings for major oxides and trace elements. PC1, PC2, PC3, PC4 and PC5 accounted for $65.8 \%, 18 \%, 7.32 \%, 5.6 \%$ and $2.10 \%$ respectively. Interpretation of PCA patterns factor loadings greater than 0.71 is typically considered excellent, while those less than 0.32 are regarded as very poor (Nowak 1998). Except for $\mathrm{Zn}, \mathrm{Rb}, \mathrm{Sr}, \mathrm{Zr}, \mathrm{Nb}$, Ta and $\mathrm{Ba}$, the remaining trace 
elements and major oxides were less than 0.32 in the five rotated factors. Factor 2 accounted for $18 \%$, where $\mathrm{Zn}$ and $\mathrm{Zr}$ were closely associated. Vanadium was found to be associated with $\mathrm{Ni}$ and $\mathrm{Zr}$ in $\mathrm{PC} 3$, while $\mathrm{Rb}$ was associated with $\mathrm{Sr}$ and $\mathrm{Nb}$ in PC4; making up 5.86\% of the total variance. The results indicated that the metals are associated with some rock-forming elements, which may have originated from parental materials of the sediments. Factors 2 and 3 association revealed low to moderate contamination of the metals involved as revealed by the contamination factor result.

Table 8 is the factor loadings for the metal oxides and rare-earth elements interactions from PCA. The first component explains $95.9 \%$ of the total variance and loads heavily on $\mathrm{La}, \mathrm{Ce}$ and $\mathrm{Nd}$. The loading pattern of these metals possibly reflects scarcely low contamination level.
The second and third component, loaded on $\mathrm{Y}$ and $\left(\mathrm{Al}_{2} \mathrm{O}_{3}\right.$, La Dy and Sc), accounting for $1.95 \%$ and $1.68 \%$ of the total variance. The factors loading for trace and rare-earth elements interaction are shown in Table 9. The principal components that have eigenvalues higher than one were also employed for their interactions. The first component (PC1) explains $64.5 \%$ of the total variance and loads heavily on $\mathrm{Sr}$ and $\mathrm{Ba}$. The PC2 loads heavily by $\mathrm{Zr}, \mathrm{Nb}$ and $\mathrm{Ba}$ and accounted for $18.9 \%$ of the total variance. The third and fourth component PC3 and PC4 account for 7.09\% and $5.83 \%$ respectively, and loaded by $\mathrm{Cr}, \mathrm{Rb}, \mathrm{Sr}$ and $\mathrm{Nb}$, while the PC5 accounted for $2.3 \%$ and loaded by $\mathrm{Zr}$ and $\mathrm{Ba}$. The PCA analysis results suggest that the metals that load positively on the same component are likely associated and possibly showed similar sources, distribution pattern

Table 8: Matrix of the principal analysis loadings of major oxides and rare-earth elements in the stream sediments.

\begin{tabular}{|c|c|c|c|c|c|}
\hline Oxides and elements & $\mathrm{PC} 1$ & PC2 & $\mathrm{PC} 3$ & PC4 & PC5 \\
\hline $\mathrm{SiO}_{2}$ & 0.052 & 0.759 & -0.322 & 0.129 & -0.057 \\
\hline $\mathrm{Al}_{2} \mathrm{O}_{3}$ & -0.031 & -0.226 & 0.226 & -0.542 & 0.18 \\
\hline $\mathrm{Fe}_{2} \mathrm{O}_{3}$ & -0.001 & -0.23 & 0.077 & 0.379 & 0.3 \\
\hline $\mathrm{CaO}$ & 0.001 & -0.039 & -0.002 & 0.004 & -0.112 \\
\hline $\mathrm{MgO}$ & $-9.70 \mathrm{E}-07$ & -0.087 & -0.004 & 0.101 & -0.165 \\
\hline $\mathrm{MnO}$ & 0.0001 & -0.007 & -0.007 & 0.006 & 0.016 \\
\hline $\mathrm{K}_{2} \mathrm{O}$ & -0.004 & -0.005 & -0.064 & -0.298 & 0.046 \\
\hline $\mathrm{Na}_{2} \mathrm{O}$ & -0.003 & -0.018 & -0.029 & -0.156 & -0.068 \\
\hline $\mathrm{P}_{2} \mathrm{O}_{5}$ & 0 & -0.002 & -0.001 & -0.004 & -0.004 \\
\hline $\mathrm{TiO}_{2}$ & 0.005 & 0.009 & 0.028 & 0.143 & -0.06 \\
\hline $\mathrm{Cr}_{2} \mathrm{O}_{3}$ & $1.43 \mathrm{E}-35$ & $1.93 \mathrm{E}-34$ & $-4.32 \mathrm{E}-03$ & $1.07 \mathrm{E}-33$ & $-8.72 \mathrm{E}-33$ \\
\hline $\mathrm{La}$ & 0.385 & 0.006 & 0.158 & 0.0771 & 0.551 \\
\hline $\mathrm{Ce}$ & 0.836 & -0.135 & -0.153 & -0.182 & -0.396 \\
\hline $\operatorname{Pr}$ & 0.096 & 0.019 & 0.018 & 0.046 & 0.045 \\
\hline $\mathrm{Nd}$ & 0.354 & 0.086 & 0.079 & 0.324 & 0.343 \\
\hline Sm & 0.081 & -0.009 & 0.03 & -0.085 & 0.067 \\
\hline $\mathrm{Eu}$ & 0.002 & -0.014 & 0.017 & 0.03 & -0.079 \\
\hline Gd & 0.057 & -0.003 & 0.051 & -0.06 & 0.04 \\
\hline $\mathrm{Tb}$ & 0.008 & 0.005 & 0.015 & -0.038 & 0.032 \\
\hline Dy & 0.026 & 0.072 & 0.139 & -0.094 & 0.125 \\
\hline Ho & 0.002 & 0.018 & 0.025 & 0.009 & -0.008 \\
\hline $\mathrm{Er}$ & 0.001 & 0.043 & 0.094 & 0.0712 & -0.11 \\
\hline $\mathrm{Tm}$ & 0.0002 & 0.006 & 0.011 & 0.006 & -0.011 \\
\hline $\mathrm{Yb}$ & 0.0007 & 0.052 & 0.083 & 0.052 & -0.068 \\
\hline $\mathrm{Lu}$ & 0.0003 & 0.008 & 0.013 & 0.002 & -0.013 \\
\hline $\mathrm{Sc}$ & -0.0007 & -0.26 & 0.352 & 0.455 & -0.422 \\
\hline $\mathrm{Y}$ & 0.065 & 0.454 & 0.785 & -0.143 & -0.141 \\
\hline
\end{tabular}


Table 9: Matrix of the principal analysis loadings of trace and rare-earth elements in the stream sediments.

\begin{tabular}{|c|c|c|c|c|c|}
\hline Elements & PC1 & $\mathrm{PC} 2$ & PC3 & PC4 & PC5 \\
\hline V & -0.0009 & 0.014 & 0.263 & -0.059 & 0.166 \\
\hline $\mathrm{Cr}$ & 0.27 & 0.191 & 0.632 & 0.041 & -0.237 \\
\hline $\mathrm{Co}$ & 0.024 & 0.02 & $0 .-065$ & 0.018 & -0.018 \\
\hline $\mathrm{Ni}$ & 0.052 & 0.047 & 0.295 & 0.06 & -0.14 \\
\hline $\mathrm{Cu}$ & -0.004 & 0.013 & 0.039 & -0.038 & -0.039 \\
\hline $\mathrm{Zn}$ & -0.129 & 0.295 & -0.221 & -0.479 & -0.149 \\
\hline $\mathrm{Rb}$ & 0.07 & 0.201 & 0.101 & 0.406 & -0.17 \\
\hline $\mathrm{Sr}$ & 0.76 & 0.201 & 0.101 & 0.406 & -0.17 \\
\hline $\mathrm{Zr}$ & -0.555 & 0.405 & 0.311 & 0.234 & 0.352 \\
\hline $\mathrm{Nb}$ & -0.157 & 0.315 & -0.547 & 0.379 & -0.271 \\
\hline Mo & $4.30 \mathrm{E}-05$ & -0.0003 & -0.0002 & -0.002 & -0.001 \\
\hline Cs & 0.009 & -0.012 & 0.021 & -0.027 & -0.02 \\
\hline $\mathrm{Ba}$ & 0.723 & 0.41 & -0.198 & 0.065 & 0.311 \\
\hline $\mathrm{Hf}$ & -0.017 & 0.019 & 0.0008 & 0.016 & 0.017 \\
\hline $\mathrm{Ta}$ & -0.048 & 0.026 & -0.011 & 0.296 & -0.635 \\
\hline $\mathrm{Pb}$ & 0.015 & 0.008 & -0.038 & 0.019 & 0.033 \\
\hline Th & -0.023 & 0.074 & -0.056 & 0.036 & 0.106 \\
\hline $\mathrm{U}$ & -0.001 & 0.016 & -0.027 & 0.019 & 0.033 \\
\hline $\mathrm{La}$ & -0.044 & 0.112 & 0.002 & 0.084 & 0.132 \\
\hline $\mathrm{Ce}$ & -0.089 & 0.251 & 0.0007 & 0.212 & 0.251 \\
\hline $\operatorname{Pr}$ & -0.001 & 0.028 & 0.0006 & 0.021 & 0.03 \\
\hline $\mathrm{Nd}$ & -0.041 & 0.105 & 0.003 & 0.071 & 0.11 \\
\hline $\mathrm{Sm}$ & -0.009 & 0.023 & $-2.00 \mathrm{E}-05$ & 0.02 & 0.023 \\
\hline $\mathrm{Eu}$ & -0.0003 & 0.0008 & 0.003 & 0.001 & $6.00 \mathrm{E}-05$ \\
\hline $\mathrm{Gd}$ & -0.007 & 0.015 & 0.002 & 0.013 & 0.02 \\
\hline $\mathrm{Tb}$ & -0.001 & 0.002 & -0.004 & 0.002 & 0.004 \\
\hline Dy & -0.006 & 0.003 & 0.002 & 0.004 & 0.019 \\
\hline Ho & -0.0009 & -0.0002 & 0.0009 & -0.0003 & 0.002 \\
\hline Er & -0.002 & -0.002 & 0.006 & -0.002 & 0.004 \\
\hline $\mathrm{Tm}$ & -0.003 & -0.002 & 0.003 & -0.003 & 0.003 \\
\hline $\mathrm{Yb}$ & -0.002 & -0.002 & 0.003 & -0.003 & 0.003 \\
\hline $\mathrm{Lu}$ & -0.004 & -0.0003 & 0.0006 & -0.0002 & 0.0007 \\
\hline $\mathrm{Sc}$ & -0.0007 & -0.0008 & 0.036 & -0.005 & -0.015 \\
\hline Y & -0.026 & -0.007 & 0.024 & 0.0009 & 0.061 \\
\hline
\end{tabular}

and/or possibly affected by the same factors in the stream sediments.

\section{CONCLUSIONS}

This study revealed that the mean values of $\mathrm{V}, \mathrm{Co}, \mathrm{Cu}, \mathrm{Zr}$, $\mathrm{Nb}, \mathrm{Hf}, \mathrm{Th}, \mathrm{Mo}$ and REEs: La, Ce, Pr, Nd, Sm, Sc, are be- low the background values, while $\mathrm{Cr}, \mathrm{Ni}, \mathrm{Zn}, \mathrm{Rb}, \mathrm{Sr}, \mathrm{Cs}, \mathrm{Ba}$ and the REEs: Eu, Gd, Tb, Dy, Er, Tm, Yb, Lu, Y, exceeded the background values. The average EF values of $\mathrm{Rb}, \mathrm{Zr}$, $\mathrm{Hf}, \mathrm{U}$ and $\mathrm{Cs}$ indicate moderate enrichment, while $\mathrm{Nb}$ has significant enrichment. The study also classified the metals as non-contaminated to very low contamination, while Ta and $\mathrm{Nb}$ showed a high degree of contamination. The results 
showed the PLI values of approximately 1, which indicates only baseline levels of metals. The geoaccumulation index (Igeo) of the elements revealed uncontaminated to moderately contaminated, except for Cs and Ta with strongly to extremely contaminated status. The LREE/HREE ratios for the stream sediments range from 6.7 to 12.9 with an average of 9.13 . The $(\mathrm{La} / \mathrm{Yb}) \mathrm{n}$ ratios indicate very high erosional rates, which suggests that La was removed from the crustal source through the weathering process, which was later transported and deposited by the streams.

\section{REFERENCES}

Abrahim, G.M.S. and Parker, R.J. 2008. Assessment of heavy metal enrichment factors and the degree of contamination in marine sediments from Tamaki Estuary, Auckland, New Zealand. Environ. Monit. Assess., 136: 227-238.

Afkhami, F., Karbassi, A.R., Nasrabadi, T. and Vosoogh, A. 2013. Impact of oil excavation activities on soil metallic pollution: Case study of an Iran Southern Oil Field. Environ. Earth Sci., 70(3): 1219-1224.

Ajibade, A. C., Woakes, M. and Rahaman, M. A. 1987. Proterozoic crustal development in the Pan- African regime of Nigeria. American Geophysic. J., 259-271.

Akinola, O.O., Okunlola, O.A. and Obasi, R.A. 2014. Compositional characteristics and industrial potential of lateritic clay deposit in Ara-Ijero Ekiti Areas, Southwestern Nigeria. Inter. J. Sci. Tech. Research, 3(3): 278-284.

Black, R., Caby, R., Monssine Pouchkin, A., Bayer, R., Bertrand, J. M., Bourllier, A. M., Fabri, J. and Lesquer, A. 1979. Evidence for late Precambrian plate tectonics in West Africa. Nature, 278: 223-227.

Buat-Menard, P. and Chesselet, R. 1979. Variable influence of the atmospheric flux on the trace metal chemistry of oceanic suspended matter. Earth and Planetary Sci. Letters, 42: 398-411.

Burg, J. P., Brunel, M., Gapais, D., Chen, G. M. and Liu, G. H. 1984. Deformation of the crystalline main central sheet in southern Tibet (China). J. Struc. Geol., 6: 535-542.

Burke, K.C. and Dewey, J.F. 1972. Orogeny in Africa. In: Dessauvagie T.F.J., Whiteman A.J. (eds.), Africa Geology. University of Ibadan Press, Ibadan, pp. 583-608.

Castor, B. and James, B. H. 2006. Rare earth elements. In E. K. Jessica, C. T. Nikhil, M. B. James (eds.), Industrial Minerals and Rocks. Society for Mining, Metallurgy and Exploration, pp. 769-792.

Chen, C., Jia, C.J., Xiong, F. and Lu, Y. 2013. Heavy metal concentrations in soil and agricultural products near an industrial district. J. Environ. Studies, 22: 1357-1362.

Chen, Z. H. 2011. Global rare earth resources and scenarios of future rare earth industry. J. Rare Earths, 29: 1-6.

Demie, G. 2015. Analyzing soil contamination status in garage and auto mechanical workshops of Shashemane City: implication for hazardous waste management. Environ. Systems Resea, 4(15): 1-9.

EPA 2012. Rare Earth Elements: A Review of Production, Processing, Recycling, and Associated Environmental Issues. EPA600/R-12/572.

Fagbote, E.O. and Olanipekun, E. 2010. Speciation of heavy metals in soil of Bitumen deposit impacted area of western Nigeria. European J. Scient. Resear. 47: 265-277.

Förstner, U. 1983. Assessment of metal pollution in rivers and estuaries. In: Thornton, I. (ed.), Applied Environmental Geochemistry, Academic Press, London, pp. 395-423.

Förstner, U., Ahlf, W., Calmano, W. and Kersten, M. 1991. Sediment criteria development. In: Heling, D., Rothe, P., Förstner, U. and Stoffers, P. (eds), Sediments and Environmental Geochemistry. Springer-Verlag, pp. 312-338.
Gansser, A. 1983. Geology of Bhutan Himalayas: Denkenschrift der Schweizerischen Naturforschenden Gesellschaft. Band. 96, Basel, Birkhäuser, pp.181.

Grunsky, E.C., Drew, L.J. and Sutphin, D.M. 2009. Process recognition in multi-element soil and stream-sediment geochemical data. Appl. Geochem., 24: 1602-1616.

Hakanson, L. 1980. An ecological risk index for aquatic pollution control, a sedimentological approach. Water Res., 14: 975-1001.

Halamic, J., Peh, Z., Bukovec, D., Miko, S. and Galovic, L. 2001. A factor model of the relationship between stream sediment geochemistry and adjacent drainage basin lithology, Medvednica Mt. Croatia. Geol. Croat., 54(1): 37-51.

Hale, M. and Plant, J. (eds.), 1994. Drainage Geochemistry, Handbook of Exploration Geochemistry. Amsterdam; New York, Elsevier 6: pp. 3-766.

Hernandez, L., Probst, A., Probst, J.L. and Ulrich, E. 2003. Heavy metal distribution in some French forest soils: Evidence for atmospheric contamination. Sci. Total Environ., 312: 195-219.

Hirano, S. and Suzuki, K.T. 1996. Exposure, metabolism and toxicity of rare earths and related compounds. Environ. Health Perspec., 104: $85-95$.

Howarth, R.J. and Thornton, I. 1983. Regional geochemical mapping and its application to environmental studies. In: Thornton, I. (ed.), Applied Environmental Geochemistry. Academic Press, London, pp. 395-423.

Kar, D., Sur, P., Mandal S.K., Saha T. and Kole, R.K. 2008. Assessment of heavy metal pollution in surface water. Int. J. Environ. Sci. Tech., 5: $119-124$.

Kennedy, W.Q. 1965. The influence of basement structure on the evolution of coastal (Mesozoic and Tertiary Basin of Africa) In: Salt basins around Africa. London Institute of Petroleum, p. 16.

Levinson, A. A. 1974. Introduction to Exploration Geochemistry. Applied Publ. Co., Calgary, p. 612.

Likuku, A.S., Mmolawa, K.B. and Gaboutloeloe, G.K. 2013. Assessment of heavy metal enrichment and degree of contamination around the copper-nickel mine in the Selebi Phikwe Region, Eastern Botswana. Environ. Ecol. Resear., 1(2): 32-40.

Lin, C., He, M., Zhou, Y., Guo, W. and Yang, Z. 2008. Distribution and contamination assessment of heavy metals in sediment of the second Songhua River, China. Environ. Monitor, Assess., 137: 329-342.

Loska, K., Cebula, J., Pelczar, J., Wiechula, D. and Kwapuli'nski, J. 1997. Use of enrichment, and contamination factors together with geoaccumulation indices to evaluate the content of $\mathrm{Cd}, \mathrm{Cu}$, and $\mathrm{Ni}$ in the Rybnik Water Reservoir in Poland. Water, Air, and Soil Pollution, 93: 347-365.

Loska, K., Wiechula, D. and Korus, I. 2004. Metal contamination of farming soils affected by industry. Environ. Interna., 30: 159 -165.

Loska, K., Wiechula, D., Barska, B., Cebula E. and Chojnecka A. 2003. Assessment of arsenic enrichment of cultivated soils in Southern Poland. Pol. J. Environ Stud., 12:187- 92.

McLennan, S. M. 1988. Recycling of the continental crust. Pure Appl. Geophys., 128: 683-724.

McLennan, S.M. 1989. Rare earth elements in sedimentary rocks: Influence of provenance and sedimentary processes. Rev. Mineral., 21: 116-200.

Mediolla, L. L., Domingues, M. C. D. and Sandoval, M. R. G. 2008. Environmental assessment of an active tailings pile in the State of Mexico (Central Mexico). Res. J. Environ. Sci., 2(3): 197-208.

Muller, G. 1969. Index of geoaccumulation in sediments of the Rhine river. J. Geol., 2:108-118.

Nair, I.V., Singh, K., Arumugam, M., Gangadhar K. and Clarson, D. 2010. Trace metal quality of Meenachil River at Kottayam, Kerala (India) by principal component analysis. World Appl. Sci. J., 9:1100-1107.

Nartey, V. K., Klake, R. K., Hayford, E. K., Doamekpor, L. K. and Appoh, R. K. 2011. Assessment of mercury pollution in rivers and streams 
around artisanal gold mining areas of the Birim North District of Ghana. J. Environ. Protect., 2:1227-1239.

Nowak, B. 1998. Contents and relationship of elements in human hair for non-industrialised population in Poland. Sci. Total Environ., 209(1): 59-68.

Nurnberg, H.W. 1982. Voltametric trace analysis in ecological chemistry of toxic metals. Pure and Appl. Chem., 54(4): 853-878.

Ochieng, E.Z., Lalah, J.O. and Wandiga, S.O. 2007. Analysis of heavy metals in water and surface sediment in five rift valley lakes in Kenya for assessment of recent increase in anthropogenic activities. Bulletin Environ. Contam. Toxicol., 79: 570-576.

Ojo, J. and Oketayo, O. 2006. Trace elements in the food chain- environmental impact of small scale/artisanal gold mining in Ile-Ife 2: Heavy metal contamination of water. Proceedings of an International Symposium on Trace Elements in the Food Chain, Budapest, Hungary, 25-27 May, 201-205.

Okunlola, O. A. and Akinola, O.O. 2010. Petrochemical characteristics of the Precambrian rare metal pegmatite of Oke Asa area, southwestern Nigeria: Implication for Ta-Nb mineralization. RMZ- Materials and Geo environment, 57(4): 525-538.

Okunlola, O.A. 2005. Metallogeny of Ta-Nb mineralization of Precambrian pegmatite of Nigeria. Mineral Wealth, p.137.

Ong, M.C., Menier, D., Shazili, N. and Kamaruzzaman, B.Y. 2013. Geochemical characteristics of heavy metals concentration in sediments of Quiberon bay waters, South Brittany, France. Oriental J. Chem., 29: 39-45.

Oyawoye, M.O. 1972. The basement complex of Nigeria. In: Dessauvagie T.F.J., Whiteman A.J. (eds.) African geology. Ibadan University Press, pp. 66-102.

Priju, C.P. and Narayana, A.C. 2006. Spatial and temporal variability of trace element concentrations in a Tropical Lagoon, Southwest Coast of India: Environmental implications. Proceedings of the 8th International Coastal Symposium, 2: 1053-1057.

Rahaman, M.A. 1976. Review of the basement geology of South-Western Nigeria. In: Kogbe C.A. (ed.) Geology of Nigeria, 2nd (ed.), Elizabethan Publishers, Lagos, pp. 41-58.

Rahaman, M.A. 1988. Recent advances in the study of the basement complex of Nigeria. In: Geological Survey of Nigeria (ed.) Precambrian Geology, Nigeria, pp. 11-43.

Rahaman, M.A. and Ocan, O. 1978. On relationships in the Precambrian Migmatite-gneisses of Nigeria. Nig. J. Min. Geol., 15: 23-32.

Ramesh, R., Ramanathan, A. L., Ramesh, S., Purvaja, R. and Subramanian, V. 2000. Distribution of rare earth elements and heavy metals in the surficial sediments of the Himalayan river system. Geochem. J., 34: 295-319.

Reimann, C. and Melezhik, V. 2001. Metallogenic provinces, geochemical provinces and regional geology-what causes large-scale patterns in low density geochemical maps of the C-horizon of podzols in Arctic Europe. Appl. Geochem., 16: 963-983.
Rose, A.W., Hawkes, M.E. and Webb, J.S. 1979. Geochemistry in Mineral Exploration. 2nd ed., Academic Press, pp. 657.

Salomons, W. and Forstner, U. 1984. Metals in the Hydrocycle. Springer-Verlag Berlin Heidelberg, pp. 352.

Senesi, G.S., Baldassarre, G., Senesi, N. and Radina, B. 1999. Trace element inputs into soils by anthropogenic activities and implications for human health. Chemosphere, 39: 343-377.

Sholkovitz, E.R. 1993. The geochemistry rare earth elements in the amazon river Estuary. Geochem. Cosmochim. Acta., 57: 2181-2190.

Sholkovitz, E.R. 1995. The aquatic chemistry of rare earth elements in rivers and estuaries. Aqua. Geochem., 1: 1-34.

Singh, M., Ansari. A.A., Muller, G. and Singh, I.B. 1997. Heavy metals in freshly deposited sediments of the Gomati river a tributary of the Ganga River: Effects of human activities. Environ. Geol., 29: 246-252.

Sofianska, E. and Michailidis, K. 2013. Environmental impact of a large scale Manganese mining activity in drama district, Macedonia, Northern Greece. 13th SGEM Geoconference on Ecology, Economics, Education and Legislation, June 16-22, 1: 393-400.

SSSA 2008. Glossary of Soil Science Terms. Committee SSGT, Ed., Soil Science Society of America, 92.

Sutherland, R.A. 2000. Bed sediment-associated trace metals in an urban stream, Oahu, Hawaii. Environ. Geol., 39(6): 611-626.

Taylor, S.R. and McLennan, S.M. 1985. The Continental Crust: Its Composition and Evolution. Blackwell, Oxford, p. 312.

Taylor, S.R. and McLennan, S.M. 1995. The geochemical evolution of the continental crust. Rev. Geophys., 33: 241-265.

Tijani, M.N., Onodera, S. and Adeleye, M.A. 2005. Environmental implications of adsorbed and total trace metals concentrations in bottom-sediments of an urban drainage network in a developing country. Materials and Geo Environ., 52(1): 127-130.

Tomlinson, D.L., Wilson, J.G., Harris, C.R. and Jeffney, D.W. 1980. Problems in the assessment of heavy metal levels in estuaries and the formation of a pollution index. Helgol. Wiss. Meeresunters, 33: 566-572.

Toyoda, K., Nakumara, Y. and Masuda, A. 1990. Rare earth elements of pacific pelagic sediments. Geochim. Cosmochim. Acta., 54: 1053-1103.

Turekian, K.K. and Wedepohl, K.H. 1961. Distribution of the elements in some major units of the earth's crust. American Geol. Soc. Bull., 72: 175-182.

Turner, D.G. 1983. Upper Proterozoic schist belts in the Nigerian sector of the Pan-African province of West Africa. Prec. Res., 21: 55-79.

Wakida, F.T.D., Lara-Ruiz, E.J. and Temores, P. 2008. Heavy metals in sediments of the Tecate River, Mexico. Environ. Geol., 54: 637-642.

Ward, J. H., Jr. 1963. Hierarchical grouping to optimize an objective function. J. American Statist. Associa., 58: 236-244.

Zhang, J. and Liu, C.L. 2002. Riverine composition and estuarine geochemistry of particulate metals in China-weathering feature, anthropogenic impact and chemical fluxes. Estuar. Coast. Shelf, 54: 1051-1070.

Zhuang, P., Li, Z., Zou, B., Xia, H. and Wang, G.I. 2013. Heavy metal contamination in soil and soybean near the Daboshan mine, South China. Pedosphere, 23: 298-304. 